The Relation of Pheasants

to Agriculture

In Montana . .
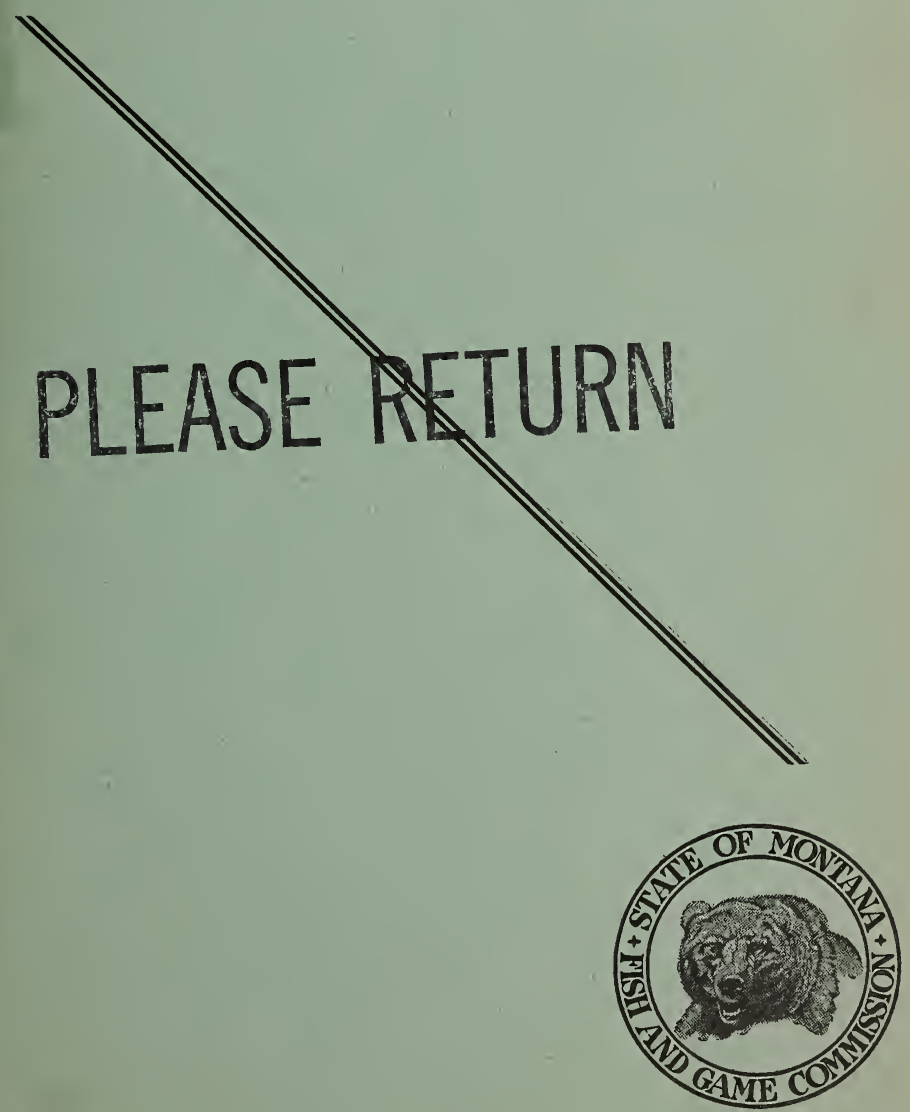


\section{DATE DUE}

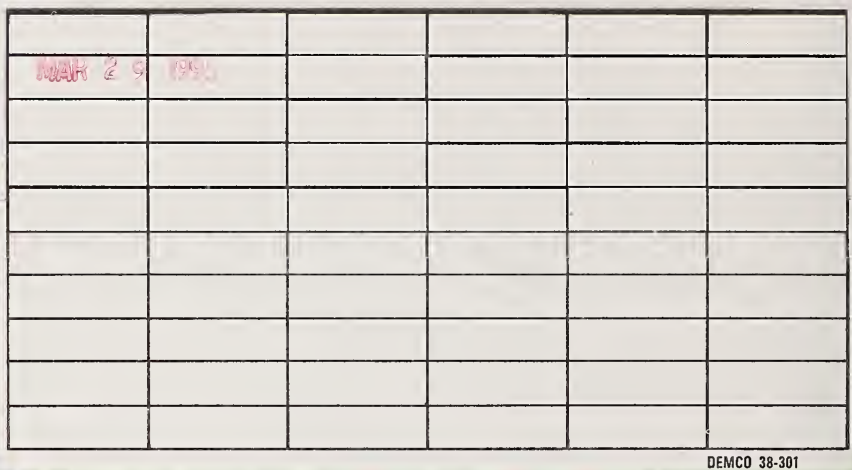




\title{
THE RELATION OF PHEASANTS TO AGRICULTURE IN THE YELLOWSTONE AND BIG HORN RIVER VALLEYS OF MONTANA
}

\author{
By \\ Robert W. Hiatt *
}

Field Work by William R. Bergeson

Wildlife Restoration Project

Montana 1-R

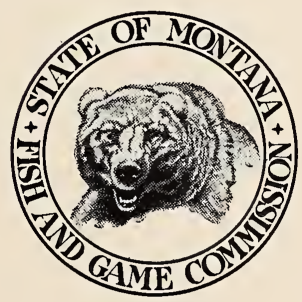

Published by

THE MONTANA STATE FISH AND GAME COMMISSION

WILDLIFE RESTORATION DIVISION

1947

* Now Chairman Department of Zoology and Entomology
University of Hawaii, Honolulu, T. H. 


\section{Digitized by the Internet Archive in 2013}




\section{TABLE OF CONTENTS}

Introduction

Purpose of study 5

Acknowledgements 5

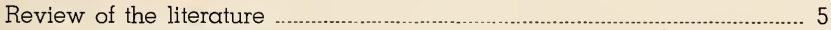

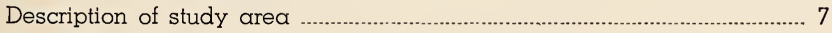

Climate of the study area ....................................................................... 9

Pheasant population in the study area ............................................ 9

Methods of study

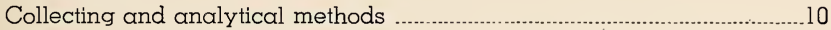

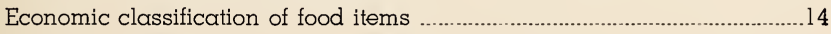

Results of observations and analyses

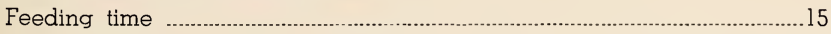

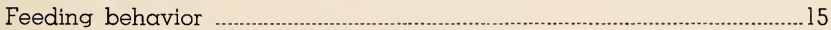

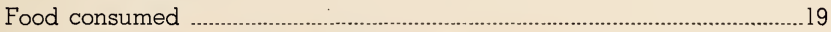

Economic relationships of the food and feeding habits .................................4

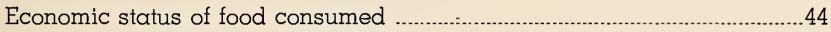

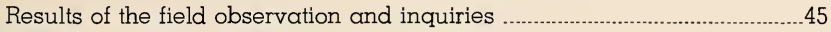

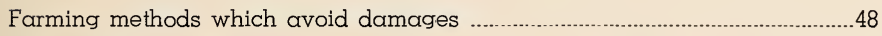

Beneficial influences of pheasants on agriculture and the community..............50

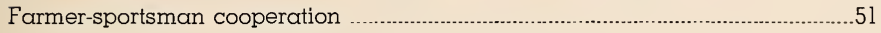

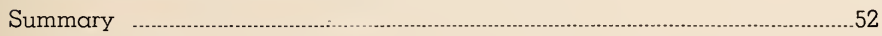

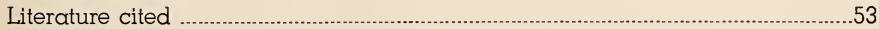

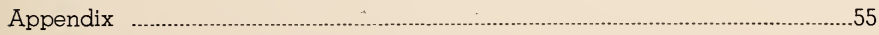





\section{INTRODUCTION}

\section{Purpose of Study}

There is considerable controversy over the influence of the ring-necked pheasant on agriculture in Montana. According to one school of thought, the benefits which accrue from the eating of various weed seeds and injurious insects by pheasants more than offset the damages pheasants do to growing crops. According to the contrary opinion, the damages outweigh the benefits and pheasants cause a net economic loss to the farmer. This paper reports the findings of a food habits study which was designed to clarify this controversy. The study was carried out in two areas of the state where pheasants are especially abundant and where, therefore, they are capable of causing the greatest damage. The author believes that the results provide a good many clear-cut answers to questions raised by advocates of both sides of the issue.

\section{Acknowledgements}

This study was undertaken and financed by the State of Montana Fish and Game Department with the assistance of Federal Aid to Wildlife funds. This paper represents an account of a portion of project I-R (1943) of the Wildlife Restoration Division. I am greatly indebted to William and Ruth Bergeson, Wildlife Technicians of the Wildlife Restoration Division, for carrying out most of the field duties, as well as many of the analyses made in the laboratory. The State. Fish and Game Commission, Robert F. Cooney (Director of the Wildlife Restoration Division), and Hector LaCasse have contributed greatly to this study, the latter being responsible for the illustrations. Mildred E. Hollensteiner, and Bertha Thompson, seed analysts of the Montana Grain Inspection Laboratory gave assistance in the identification of seeds. Dr. H. B. Mills of the Department of Zoology and Entomology, Montana State College, aided in identification of the insects. Dr. Edward Booth and Professor Elwood Morris of the Department of Botany identified many of the leaves and fruits. Montana State College generously provided working space and equipment. The Agricultural War Board of Yellowstone County, the Montana State College Experimental Farm at Huntley, and the Holly Sugar Corporation provided assistance in ways too numerous to mention. I am indeed grateful for the excellent cooperation given the project by the agriculturists of the study area.

\section{Review of the Literature}

Food habits of ring-necked pheasants have been investigaicd to some extent by other workers throughout the United States and Canada. Earlier studies, for the most part, were concerned with the relation of the birds to agriculture. Many of the more recent investigations were undertaken to aid in management programs for increasing the pheasant population. Those investigations of food habits which had their findings expressed as percentage values are compared in table 1. 


\begin{tabular}{|c|c|c|c|c|}
\hline 尝 & 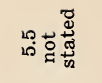 & 宽 & $\stackrel{n}{\wedge}$ & $\infty$ 守 \\
\hline ฐ & 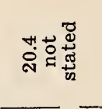 & 离 & ભ & 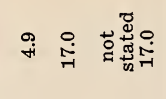 \\
\hline 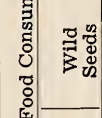 & के & 苟 & స్ㄱ & न \\
\hline 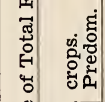 & 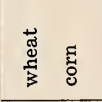 & ğ & 횽 & 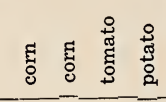 \\
\hline 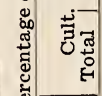 & 要 & ¿̊. & 品 & 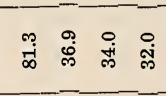 \\
\hline 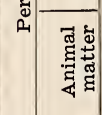 & 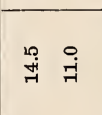 & $\stackrel{\circ}{\circ}$ & ભ & 广ீ \\
\hline 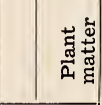 & 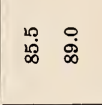 & मे & to & 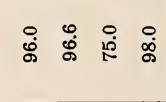 \\
\hline 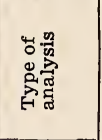 & 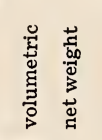 & 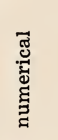 & 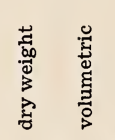 & 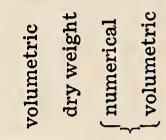 \\
\hline 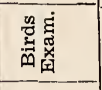 & 喿 & ळ & జ్ల ఖ్ & 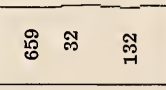 \\
\hline 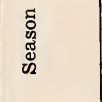 & 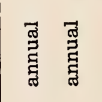 & 蚝 & 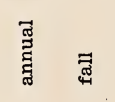 & 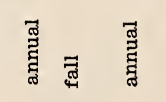 \\
\hline 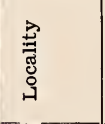 & 㺃 & ‡̊ & 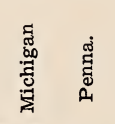 & 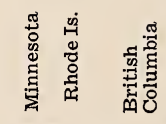 \\
\hline คัँ & 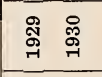 & 怘 & 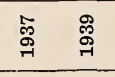 & 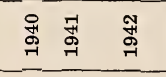 \\
\hline 苍 & 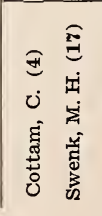 & 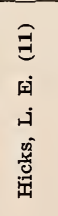 & 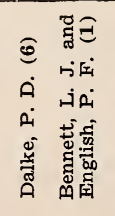 & 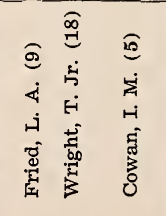 \\
\hline
\end{tabular}


Three studies in which the findings were not expressed as percentage values should also be mentioned here. Burnett (2) and Maxson (12), independently in Colorado studied the food habits of a few pheasants throughout the year. The data were interpreted with respect to the harmful or beneficial character of each pheasant meal. A more extensive study of the food habits of the pheasant was under taken in South Dakota by Severin (15), who analyzed the crops and gizzards of 285 birds taken throughout the year. This investigation was made to ascertain the pheasant's effect on agriculture in that state; the results were set forth on a numerical basis with no percentages computed. Corn was the leading food item, with other grains and noxious weeds contributing a substantial amount.

In addition to the above investigations, various minor accounts and notes concerning the food habits of the pheasant are to be found in ornithological literature. It is apparent that in the states in which studies have been made, the pheasant is essentially granivorous, approximately three-fourths of its food on the average consisting of cultivated grains. It has likewise been shown that where grains are not available, the birds will readily adapt themselves to other sources of nutriment.

\section{Description of the Study Area}

The location of the study area is shown in figure 1.

\section{MUNTANA}

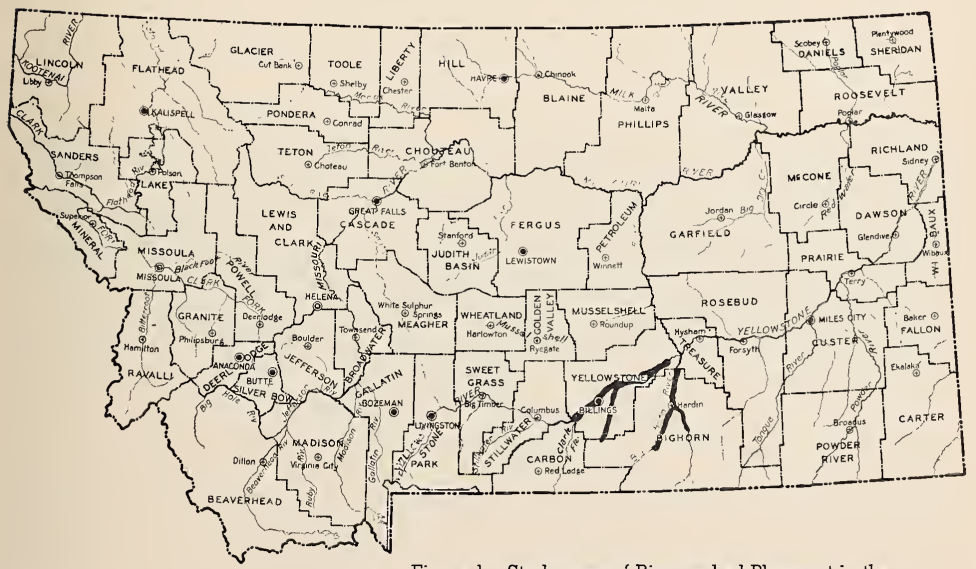

Figure 1. Study area of Ring-necked Phecisant in the Yellowstone and Big Horn River Valieys.

The variety of agricultural crops cultivated, the extensive acreage of wild land, and land abandoned after cultivation provided a wide diversification of habitat. According to the estimates supplied by several agricultural agencies and the Crow Indian Agency, the acreages under irrigation in the study area total 146,991, with roughly two-thirds of this area in the Yellowstone River Valley. The percentages of the land planted to various crops are 


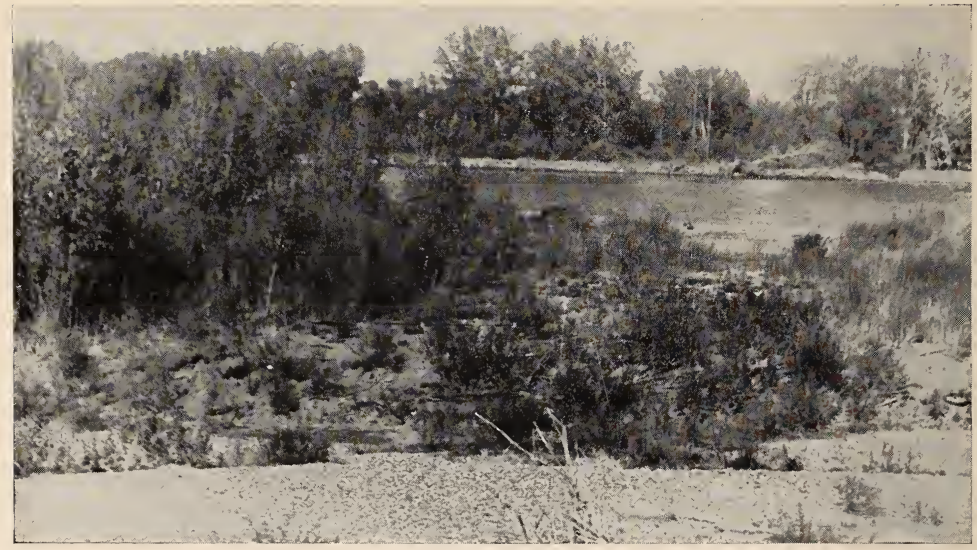

Heavy cover along Yellowstone River bottom directly adjacent to cultivated farm londs.

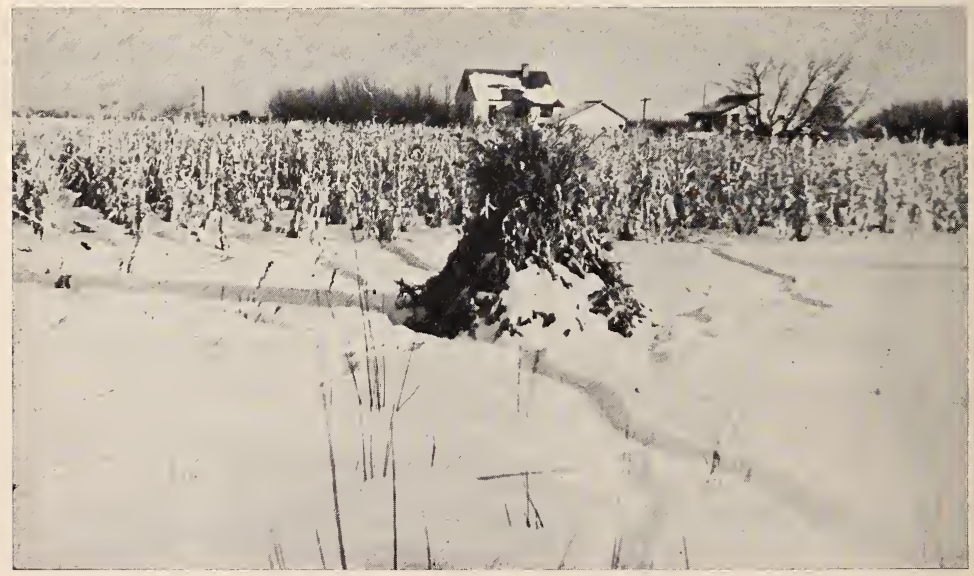

View of farming area in midwinter. Note pheasant tracks leading to and from the corn shock in foreground. 
as follows: Alfalfa forage, 24.1; fallow land, 13.1; sugar beets, 11.8; oats, 8.1; beans, 7.7; barley, 7.2; wheat, 7.0; alfalfa seed, 6.0; soil building crops, 2.4; field corn, 2.1; peas, 1.8; timothy hay, 1.7; seed beans, 1.5; pasture, 0.7; clover, 0.7; potatoes, 0.4 ; speltz, 0.3; gardens, 0.2 ; corn fodder, 0.2 ; seed clover, 0.1 ; miscellaneous, 2.9. In addition, there are many acres of uncultivated, marginal land suitable for pheasants. Plate 1 shows typical scenes of the farm land.

The adjacent and interspersed wild land presents a variety of cover types, such as sage brush flats and slopes; draws and coulees supporting dense thickets of snowberry and wild rose; and riparian cottonwood, willow, weed, and wild rose areas which are extensive along the rivers. Cultivation is not clean in most areas. Fencerows, irrigation ditches, vacant fields gone over to weeds, and road rights-of-way support a luxuriant cover with its attendant food supply within relatively short feeding range of cultivated crops.

Many of the farmers in this locality forage hogs on grain fields after harvesting, and a considerable percentage of the hailed or shattered grain is salvaged. However, because of the unbalanced ration, extensive periods of hog feeding on waste grain is not undertaken. This salvage applies primarily to grains exclusive of wheat and corn.

\section{Climate of the Study Area}

The climate of the study area is of the semiarid type. The summers are warm, often hot, and the winters are cold.

All small grains were headed out by the end of June 1943, although drought conditions and severe cold slowed plant growth during May, enabling weeds to gain a head start over the crop plants. Harvesting of dry-land grain was started in July and grain lost in transit accumulated along the road shoulders. Harvesting and threshing of grain was virtually completed by the end of August, and fall plowing had begun. Corn husking and shocking were completed by October. No snow covered the ground until the latter part of Ianuary, 1944; mild weather had prevailed through November and December. Late January winds were severe and did considerable damage to winter wheat, but the month was the mildest in the history of the State. Snow which covered the ground during February had disappeared in early March. Severe drought conditions from January through April made this period the driest in 50 years. Weeds in non-irrigated areas were retarded, but irrigated regions were not seriously affected by the drought.

\section{Pheasant Population in the Study Area}

Strip censuses were taken through typical farm land with the aid of a trained bird dog. A fixed census line was established. The shortest distance from this line to the points where pheasants flushed was recorded. From these data the width of the census strip was calculated, and the population density in birds per acre was computed. These censuses indicated an average of 2.7 birds per acre in the study area. Prior to the special hunting season of 1942, the population density was approximately 40 per cent greater. According to long-time residents, there has been no large scale fluctuation in numbers over the last few years. It is entirely possible that the great density attained in the fall of 1942 indicated a saturation point, for the food supply certainly exceeds the demand and was probably not a controlling factor in limiting the population. The sex ratio during the study period was approximately one male to three females. 


\section{Methods of Study}

\section{Collecting and Analytical Methods}

Two distinct avenues of approach were followed during this study; (1) Observations and inquiries were made in the field, and (2) pheasants were collected for analysis of food habits. Field glasses and a 16-power telescope were employed to observe the feeding habits of the birds throughout the day. Damage claims to cultivated crops were solicited through the central agencies of the Agricultural War Board and the County Agricultural Extension Agents in Yellowstone and Big Horn Counties. Each farmer claiming crop damage was visited and information was secured as indicated in the sample form shown in figure 2. In addition to the crop damage reports investigated, many farmers were interviewed for report of possible agricultural damage and for their general reaction to the pheasants.

\begin{tabular}{cccc}
$\begin{array}{l}\text { Name_and usage } \\
\text { Lamage recorded: }\end{array}$ & $\begin{array}{c}\text { Date_ance from } \\
\text { Distaner brush }\end{array}$ & $\begin{array}{c}\text { Growth } \\
\text { condition }\end{array}$ & $\begin{array}{c}\text { Approximate number of } \\
\text { plants destroyed }\end{array}$ \\
\hline Crop type & $:$ & $:$ & $:$ \\
\hline$:$ & $:$ & $:$ & \\
\hline & & $:$ & $:$ \\
\hline
\end{tabular}

Further description of domage:

Pheasant cover type nearest damage:

Collection numbers of birds taken in the vicinity:

Other remarks:

Figure 2. Crop damage report form.

Birds collected for analysis of food items were taken in areas where agricultural damage was reported and in regions where agricultural damage was likely. Five hundred pheasants were obtained, both young and adult, 13 of which had no food in their crops. Table 2 shows the number of pheasants examined each month.

Most of the birds were collected within three hours before sunset or one hour after sunset. These hours were selecied because it has been established by Burnett (2), Maxson (12), Dalke (6), and Fried (9) that two feeding periods occur each day - one terminating before $10 \mathrm{a}$. $\mathrm{m}$. and the other beginning approximately four hours before sunset. Collections made in the evening are likely to insure the maximum number of full crops. The early morning feeding period provided an opportunity to take roadside censuses and to make observations.

Of the 500 pheasants collected, 267 were adult males*/, 157 adult females, 49 juvenile females, and 27 juvenile males. No attempt was made to select birds for study, although the greater size and traditional hunting laws combined to favor the adult males in the bag. Young birds were collected in approximately the regular adult-young ratio during the reproductive season.

* / Birds were considered adults if their weight exceeded 26 ounces and if the bursa of Fabricius was absent or nearly so. 
Table 2. Number of pheasants collected during each month.

\begin{tabular}{|c|c|c|c|}
\hline Month & $\begin{array}{l}\text { Number of } \\
\text { birds } \\
\text { collected }\end{array}$ & Month & $\begin{array}{l}\text { Number of } \\
\text { birds } \\
\text { collected }\end{array}$ \\
\hline January & 26 & July .............. & 35 \\
\hline February & 26 & August & 89 \\
\hline March .... & 44 & Septembe & 61 \\
\hline April ....... & 15 & October & …..... 56 \\
\hline May ....... & ......... 89 & Novembe & 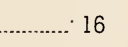 \\
\hline \multirow[t]{2}{*}{ June ....... } & 29 & Decembe & …....... 14 \\
\hline & & Total & 500 \\
\hline
\end{tabular}


The frequency with which pheasants were collected in the various cover types is indicated in table 3.

Table 3. Frequency with which birds were collected on the various cover types.

\begin{tabular}{l|c|c}
\hline Cover type & $\begin{array}{c}\text { Number of } \\
\text { birds } \\
\text { collected }\end{array}$ & $\begin{array}{c}\text { Percentage } \\
\text { of the total } \\
\text { zumber of birds }\end{array}$ \\
\hline Grain stubble & 83 & 17.0 \\
Road shoulder & 83 & 17.0 \\
Weeds and grass & 74 & 15.2 \\
Alfalfa & 65 & 13.2 \\
Ditch bank (willow, chokecherry) & 44 & 8.4 \\
Growing grain & 36 & 6.9 \\
Pasture & 29 & 5.5 \\
Plowed field & 23 & 4.4 \\
Corn & 15 & 2.9 \\
Sweet clover & 12 & 2.3 \\
Bean field (growing or harvested) & 11 & 2.1 \\
River brush & 8 & 1.5 \\
Sugar beets & 6 & 1.1 \\
Fallowed land & 5 & 1.0 \\
Peas (growing or harvested) & 3 & 0.6 \\
Seeded fields & 3 & 0.6 \\
\hline & 500 & \\
\hline & & \\
\hline
\end{tabular}

Data were recorded on special forms for each bird collected (fig. 3). The birds were numbered, placed in quick-freeze storage, and subsequently shipped to the laboratory at Montana State College where they arrived solidly frozen. Here they were weighed, sexed, inspected for the presence or absence of the bursa of Fabricius, classified as to reproductive development, and then the crops were removed. The entrance and exit of each crop were ligated, the wall was punctured, and the crop was wrapped in a numbered cheesecloth bag which was submersed in a 10 per cent solution of formalin. 
Number

Sex

Date

Time

Location

Distance from river brush from water.

Damage reported in vicinity

Cover type where collected

Cover types within quarter-mile radius

Food getting observations.

Remarks

Figure 3. Field report form for individual pheasant collections.

All figures concerning the food habits given in this paper were computed from crop contents only, since crop analysis appears to be much more reliable in ascertaining a typical pheasant meal than is analysis of the content of the gizzard or a combined analysis of the two organs (Davison, 7). Reasons for this supposition are several: (1) Crop contents are emptied rather regularly, whereas, the gizzard contents, in part, may be retained for days or even weeks at a time; (2) both soft and hard foods are generally found in perfect condition in the crop, whereas, in the gizzard the soft bodies of larval insects, earthworms, slugs, and soft fruits are ground to an unidentifiable mass shortly after their entrance; (3) gizzard contents tend to overemphasize the hard foods such as hard seeds and sclerotized arthropod integument, whereas, the crop content discloses all foods consumed in their exact proportions.

Frequency of occurrence among crops, numerical frequency of items, weight (dry for seeds and leaves, undried for animal matter and fruits), and volume were used in analyzing food items and computing percentages. This combination of methods enabled the writer to compare these analyses with those of any other investigator and also makes available these data to others who employ but one or two of the methods mentioned. Moreover, one may better appraise the omnivorous food habits and preferences if information is available from several analytical methods. By using dry weight for soft fruits and animal forms, the food constituents are expressed in more normal values and overemphasis on vegetable matter is reduced as compared to animal matter.

The technique of crop analysis was as follows: The contents of each crop were placed in a 25-mesh, shallow plankton net and washed thoroughly. The food was then placed on blotter squares and the various items were separated, identified, counted, and put separately into small vials. The plant materials, exclusive of fruits, were then dried in an electric oven at $110^{\circ} \mathrm{C}$. All items were allowed to remain in the oven until they had ceased to lose weight. A few vials were removed at one time, cooled, and weighted on a chainomatic balance sensitive to 0.001 gram; this permitted the accurate weighing of very small items. Fruits and animal matter were weighed immediately after counting; surface moisture was removed by blotting before weighing. Volumes were obtained by computing the specific gravity of the items by displacement in toluene. The displacement of toluene was likewise computed on the chain- 
omatic balance to a sensitivity of 0.0001 gram. It was found that items show remarkable constancy in specific gravity throughout the year. When the specific gravity and weight are once known for a particular item, the absolute volume may be readily determined by substitution in the formula $D=\stackrel{M}{\mathrm{v}}$. The writer believes that this method of securing volumetric data for food items is superior to others described. The inconsistency in size, shape, and flaccidity of food items precludes accurate volumetric analysis in any manner except by computation from specific gravity and weight. Moreover, the specific gravity method reduces volumetric determination to a constant which withstands repetition by other investigators.

\section{Economic Classification of Food Items}

An ideal and desirable economic classification of the food items eaten by pheasants would classify each food as harmful, neutral, or useful to the agriculturist. However, it is obvious that such a classification cannot be made with complete accuracy.

Grains are ordinarily useful to the farmer, however, many crop plants would have to be designated as neutral or harmful if they grow in places where they are not wanted. Moreover, most of the grain consumed by phesants is waste grain which cannot be considered useful to the farmer who has no way to salvage it.

An economic evaluation of weed seeds must vary with the environment. We have no certain method of determining the source of the weed seeds found in a pheasant's crop. If a crop is full of noxious weed seeds it does not follow that they were picked up in a cultivated field. However, noxious weed seeds dispersed from a waste area may ultimately germinate in cultivated land. Since pheasants are primarily dwellers on cultivated land, we may assume that any weed seeds found in their crops have come from farmed areas. Recently it has been found that seeds which pass undigested through the alimentary tract of pheasants germinate more quickly than those not exposed to such treatment (Swank, 16). Indeed, it has been recommended on management projects that advantage be taken of the capacity of pheasants to disseminate seeds of food plants in the places they frequent.

In general, what has been said of weed seeds is true of insects. Many of our insects (e. g., cutworms) can be accurately classified into economic categories because their food and feeding habits are more or less specific; others cannot. Some may be neutral if they are not attacking crop plants; others may be beneficial if they feed upon noxious weeds, while others may have food habits which range from crop plants on one occasion to neutral or noxious weeds on another. An economic classification of insects becomes increasingly complex when we consider that parasitism among them is extremely common (Severin, 15). For example, many grasshoppers are parasitized by sarcophagid maggots. Such grasshoppers die in a few days, during which time the maggots pupate, metamorphose, and produce another generation of adults. These, in turn, parasitize and destroy many more grasshoppers-more perhaps than the pheasant, which inadvertently consumed the original parasitized animal. Therefore, this pheasant is actually doing harm to the farmer when feeding on this alleged pest.

The foregoing statements serve to indicate the flexibility which must characterize any scheme of economic classification of pheasant food items. The classification embodied in this paper, therefore, will indicate the usual relation of these items to agriculture which may vary at different times and places. 
A list of all the species of plants found in pheasant crops was submitted to H. E. Morris, Extension Botanist of the Montana Agricultural Experiment Station, to be appraised for their economic relationships in the study area. The insects were classified by the author from information set forth by Essig (8) supplemented by appraisals by H. B. Mills, Montana State Entomologist. Animals other than insects were evaluated by the writer. Four categories were employed: (1) Useful (U), designating items beneficial to the farmer; (2) waste grains (Uw), indicating non-salvageable grains; (3) neutral (N), applied to items neither beneficial nor harmful to the farmer; and (4) harmful (H), consisting of those items definitely harmful to agricultural practices.

\section{Results of Observations and Analyses}

\section{Feeding Time}

Early morning roadside censuses taken throughout the year provided remarkably good opportunities for observing the activities of pheasants. Within two hours after sunrise the birds disappear from the open fields and edges of growing crops. Standing or crouching near the edge of protective cover was the only early morning activity observed during the winter. More activity was apparent during the remainder of the year, although most of the time spent in the open seemed to consist of casual exercising, not foraging. Dalke (6) reports that some feeding does occur in the morning, but no pheasant crop collected by him before noon contained more than 17 per cent of the food of the average full crop. The present study disclosed that no bird crop collected in the morning contained food in excess of one-fourth of the average full crop. Virtually no pheasant activity is apparent from two hours after sunrise to four hours before sunset. The maximum number of pheasants observed actually feeding occured one to two hours before sunset. Although no data are available on the percentage of birds feeding at this time, the crop analyses indicate that the figure is high. Further, although several investigators have mentioned two distinct daily feeding periods, it seems apparent that the most important feeding period centers around sunset.

Table 4 shows, in addition to the daily distribution of food contained in the crops per hour, the average crop volume and the number of adult birds collected in each period. The percentages are computed on the basis of the average full crop. The average of the 80 crops with a volume exceeding 15 cubic centimeters was taken as 100 per cent. On this basis it was found that the average maximum crop volume was 21.906 cubic centimeters. Table 4 also shows that all pheasants do not go to roost with full crops. The average volume of 37 crops of birds collected within one hour after sunset was just one-half the maximum. Occasionally an exceedingly heavily filled crop may be found. For example, of 500 pheasants, one was collected with 55.516 cubic centimeters of food in its crop. The contents included 207 cutworms, 25 freshwater snail shells, and several insect items. The bird was a laying female, killed 45 minutes after sunset in early May. The monthly distribution of food consumption compared with the annual average maximum crop content is presented in table 5.

\section{Feeding Behavior}

Accurate observation of feeding habits was found to presert many difficulties. Pheasants several hundred yards distant from the observer apneared disturbed, and would gradually make their way to the nearest cover. Undisturbed feeding was seldom observed. Whether or not the birds scratch with their feet for food has drawn commitment from but one investigator. Burnett (2) concluded that pheasants do not scratch because he found virtually 


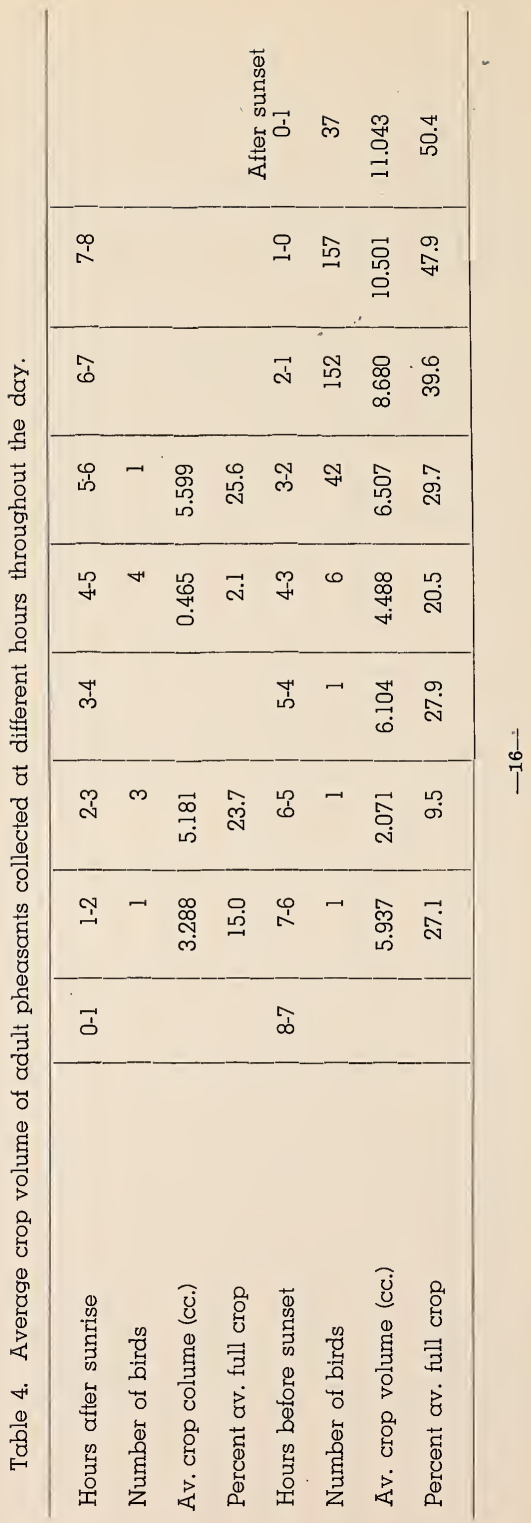


Table 5. Monthly distribution of average crop volume compared with the annual average maximum crop content.

\begin{tabular}{l|c|c}
\hline \multicolumn{1}{c|}{ Month } & Average volume & Average full crop \\
\hline & Cubic centimeters & Percent \\
January & 9.632 & 44.0 \\
February & 13.893 & 63.4 \\
March & 12.383 & 56.5 \\
April & 4.523 & 20.6 \\
May & 8.978 & 41.0 \\
June & 4.681 & 21.4 \\
July & 5.461 & 24.9 \\
August & 3.822 & 17.4 \\
September & 5.775 & 26.7 \\
October & 10.007 & 45.7 \\
November & 16.322 & 74.5 \\
December & 11.811 & 53.9 \\
\hline
\end{tabular}

no cutworms in pheasants collected in infested fields. The evidence at hand suggests that scratching in the manner of the domestic fowl is rare, but occasionally done. An adult male was observed scratching in 2 inch snow during February. The bird was shot and the area was examined. Bare patches with claw marks in the stubble field indicated that the bird was scratching for waste grain. In another instance a one-legged pheasant was observed to lie on the side bearing the stub while it scratched for waste grain in the gravel along a road shoulder.

Most of the foraging by pheasants is accomplished without scratching, and food items eaten indicate that the forage area is the ground surface or low-growing plants. However, innumerable instances of scratching or "rooting" with the beak were recorded, specially in newly manured fields or on the periphery of chaff stacks. Moreover, the pheasant's method of foraging on corn seedlings requires an excavation by the beak only.

Since the seasonal foraging range of pheasants has considerable bearing on management practices as well as on their relation to agriculture, crop types grown within a quarter-mile radius of the point of collection were recorded for each bird. A comparison was then made between the food items found in the digestive tract and the crops grown in the vicinity of collection. The evidence overwhelmingly indicated that the birds seldom ranged more than a quarter-mile during the feeding period. A slightly wider foraging range seemed to occur during the winter and spring, which is to be expected.

Comparison between the feeding habits of pheasants of the same and different ages within the same flock was made in several instances in which 
two or more birds were collected from the same group. In 17 of the 21 groups of adult birds in which the food habits were studied the birds of each group showed similarities in choice of food but not necessarily in the amounts of the items consumed. Food analyses of the hen and young of individual broods show that the choice of items eaten varies to a greater degree than it does between adults. In eight different groups from which the hen and one or more of the young were collected half showed the hen and chicks to have consumed the same leading item and half were noted to have selected different major items. In August two hens and two chicks were collected from one brood. The chicks had consumed grasshoppers and common sunflower seeds in almost identical quantities, while one hen had consumed the same two items in far greater quantities. The other hen, however, had taken several owlet-moth larvae (Noctuidae), yellow bristlegrass seeds, and leaf fragments in addition to grasshoppers and common sunflower seeds. Chicks in a brood

Figure 4. Monthly food of ring-necked pheasants by natural groups, showing the percentage frequency of occurrence and the percentage composition by number, weight and volume.

BY FREQUENCY OF OCCURRENCE

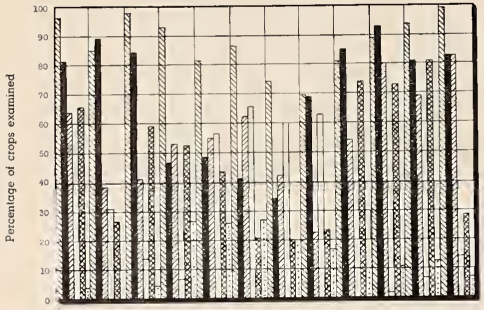

Jan. Feb Mar Apr May June July Aug Sept Oct Nov Dec

BY WEIGHI

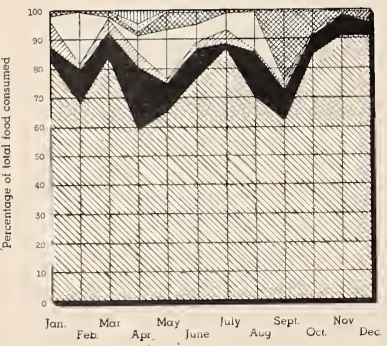

BY NUMBER

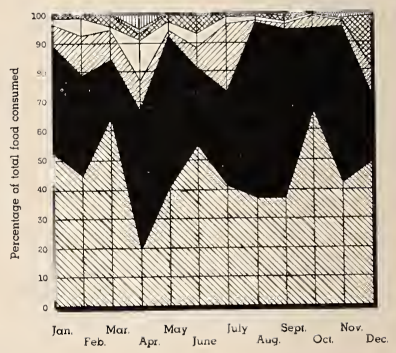

BY VOLUME

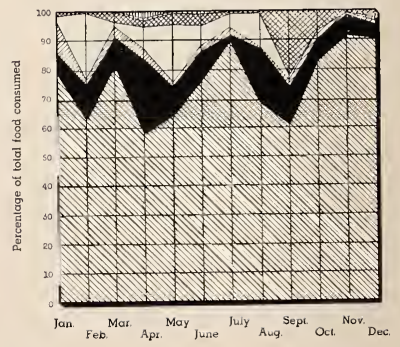

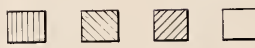

Gravel, etc Cult crops Buds \& leaves Fruits
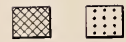

Insects Other animals Weed seeds 
generally take the same types of food, even to the same major item. However, considerable variation occurs in regard to the comparative amounts consumed. In one case where three chicks were collected from a single brood all had fed exclusively on yellow bristlegrass seeds. One had consumed 161, another 22, and the other 2 seeds. A second group of three chicks collected together had consumed the same items but the total bulk (by weight) consumed by each was $0.678,0.631$, and 0.032 grams.

\section{Food Consumed}

Analyses of the total food consumed by 500 ring-necked pheasants on a monthly basis are presenied in figure 4.

The total amounts of plant and animal food eaten each month of the year are shown in table 6 . The vegetable constituents amounted to 95.8 per cent by number, 88.4 per cent by weight, and 88.3 per cent by volume of the annual food. Animal food was eaten in each month of the year.

Table 6. A comparison between the amount of plant and animal food eaten by ring-necked pheasants for each month of the year.*

\begin{tabular}{|c|c|c|c|c|c|c|}
\hline \multirow[t]{3}{*}{ Month } & \multicolumn{6}{|c|}{ Food } \\
\hline & \multicolumn{3}{|c|}{ Plant } & \multicolumn{3}{|c|}{ Animal } \\
\hline & No. & $\mathrm{Wt}$. & Vol. & No. & $\mathrm{Wt}$. & Vol. \\
\hline January & 97.9 & 97.9 & 98.0 & 1.1 & 1.5 & 1.4 \\
\hline February & 99.2 & 99.3 & 99.7 & 0.1 & 0.1 & 0.1 \\
\hline March & 95.3 & 97.6 & 96.1 & 4.3 & 1.9 & 3.6 \\
\hline April & 90.9 & 90.9 & 94.6 & 3.2 & 4.4 & 2.7 \\
\hline May & 93.4 & 76.3 & 74.8 & 6.2 & 22.8 & 24.4 \\
\hline June & 88.6 & 89.1 & 88.6 & 10.4 & 9.9 & 10.4 \\
\hline July & 96.7 & 93.2 & 94.2 & 2.7 & 6.1 & 5.5 \\
\hline August & 97.7 & 85.9 & 87.5 & 1.8 & 13.6 & 12.2 \\
\hline September & 97.1 & 74.8 & 77.0 & 2.1 & 24.6 & 22.6 \\
\hline October & 98.1 & 92.4 & 90.1 & 1.3 & 7.2 & 6.1 \\
\hline November & 97.8 & 97.8 & 98.6 & 0.5 & 0.4 & 0.1 \\
\hline December & 81.5 & 96.6 & 96.4 & 17.6 & 2.1 & 2.7 \\
\hline
\end{tabular}

* Inanimate or non-food materials are omitted.

Analyses of the leading items of pheasant food consumed in an average daily meal each month (i.e., items representing at least 1 per cent of the total monthly consumption by number, weight, or volume) are to be found in tables 1 to 12 , Appendix. The leading food items consumed in an average daily meal for the year are listed in table 13, Appendix. Plates 2 to 13 illustrate the leading food items consumed in an average daily meal for each month of the year. Plate 14 shows the food items which the average pheasant might be expected to consume in a daily meal during the year. 
Food items which comprise one per cent or more by number, weight or volume of the average day's food for a ring-neck pheasant in the Yellowstone and Big Horn River Valleys, Montana. The number of each item illustrated represents the average number eaten.
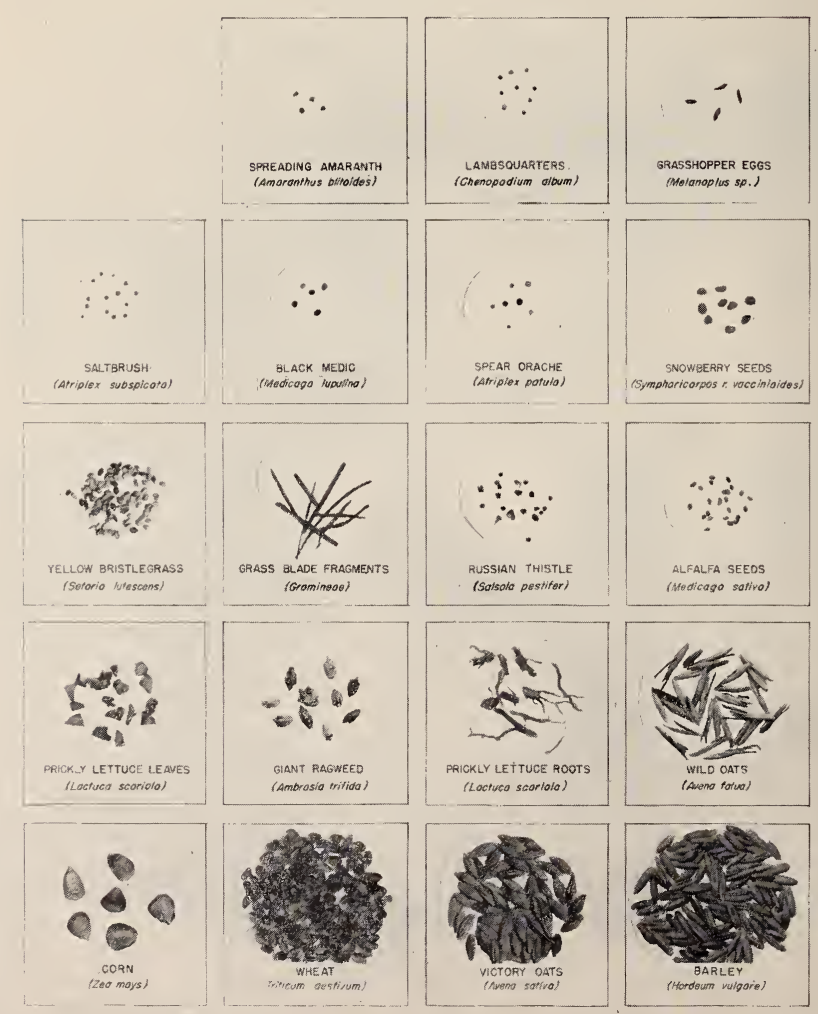


\section{FOOD ITEMS FOR FEBRUARY}

Food items which comprise one per cent or more by number, weight or volume of the average day's food for a ring-neck pheasant in the Yellowstone and Big Horn River Valleys, Montana. The number of each item illustrated represents the average number eaten.
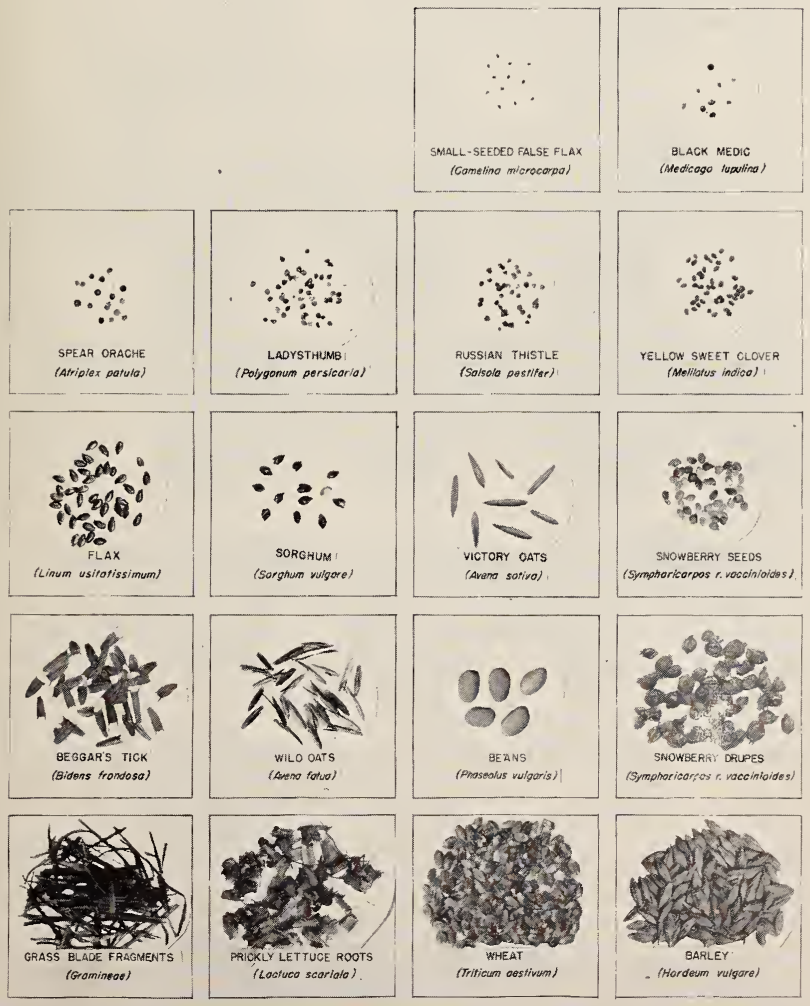


\section{FOOD ITEMS FOR MARCH}

Food items which comprise one per cent or more by number, weight or volume of the average day's food for a ring-neck pheasant in the Yellowstone and Big Horn River Valleys, Montana. The number of each item illustrated represents the average number eaten.

BIGLEAF SUMPWEED (Ive xonthitolio)

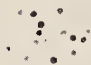

SPEAR ORACHE

RUSSIAN THISTLE (Salsolo pestifar)

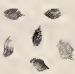

GIANT RAGWEED (Ambrosia trifido)

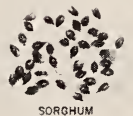

(Sorghum vulgare)

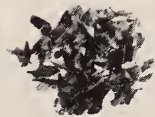

ALFALFA LEAVES (Aledicogo sotiva)

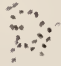

YELLOW SWEET CLOVER (Melilotus indico)

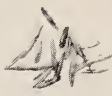

WILD OATS

(Aveng fotua)

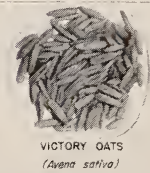

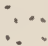

FANWEED

(Thlospi orvensa)

ALFALFA SEEOS

(Medicago sotivo)

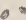

a 3

SNOWBERRY SEEOS Symahorleorpos fo ceceinioides

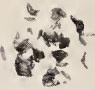

GRASSHOPPER EGSS O PODS (Metonoplus sp)
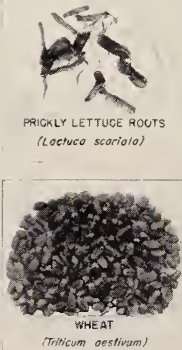
(Monolepis nuttolfiono

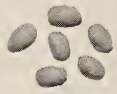

BE ANS

(Phoseolus vulgoris)

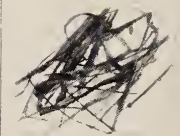

GRASS BLADE FRAGMENTS (Gramineoe)

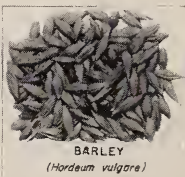


FOOD ITEMS FOR APRIL

Food items which comprise one percent or more by number, weight or volume of the average day's food for a ring-neck pheasant in the Yellowstone and Big HornRiver Valleys, Montana. The number of each item illustrated represents the average number eaten.

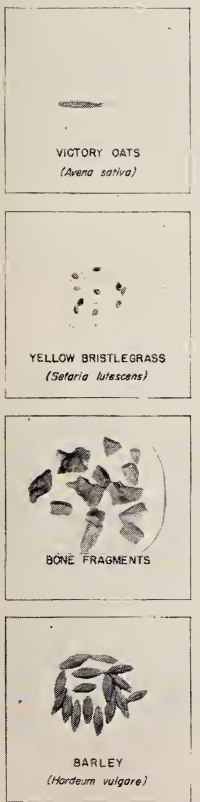

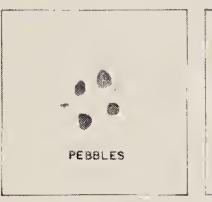

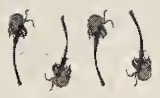

DANDELION SEEO HEADS (Toroxacum officinate)
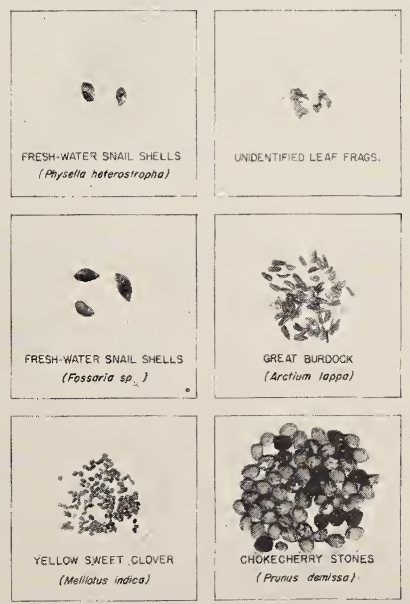

GRASS BLADF, FRAGMENTS (Grominea)

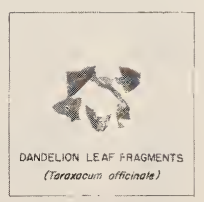

LADYSTHUME

(Poijganum persicaria)
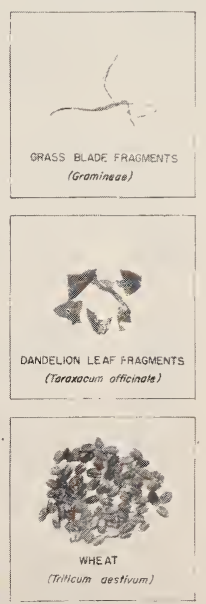
Food items which comprise one per cent or more by number, weight or volume of the average day's food for a ring-neck pheasant in the Yellowstone and Big Horn River Valleys, Montana. The number of each item illustrated represents the average number eaten.

FFESH-WATER SNAIL SHELL (Ahyseltio hoterastrapho)

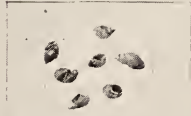

FRESH-WATER SNAIL SHELLS (Fossaria so.)

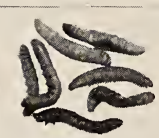

DINGHY CUTWORM (Feltio ducens)

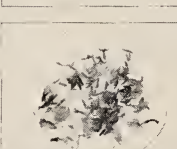

YELLOW BRISTLEGRASS (Setaria lutescens)

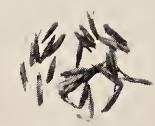

WILO OATS (Avera fatwo)

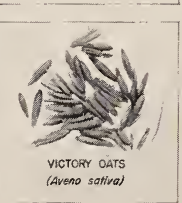
(Plontaginaceoe)
COMMON DANOELION (Toraracum officinale)

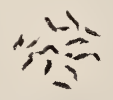

PLANTAIN SPIKES

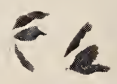

YELLOW SWEET CLONER LVS. (Mellitorus indico)

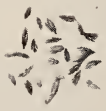

WILD BARLEY (Hordeum jubatum)
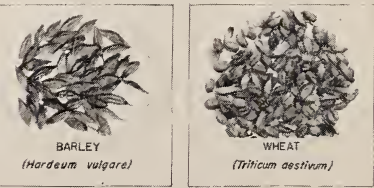
FOOD ITEMS FOR JUNE

Food items which comprise one per cent or more by number, weight or volume of the average day's food for a ring-neck pheasant in the Yellowstone and Big Horn River Valleys, Montana. The number of each item illustrated represents the average number eaten.

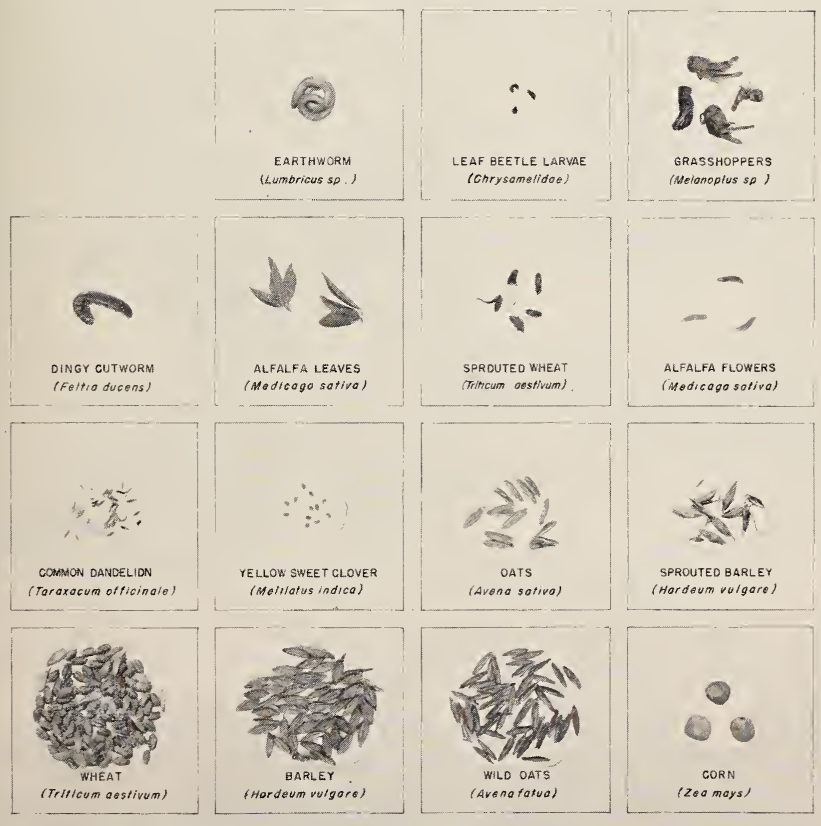




\section{FOOD ITEMS FOR JULY}

Food items which comprise one percent or more by number, weight or volume of the average day's food for a ring-neck pheas ant in the Yellowstone and Big Horn River Valleys, Montano. The number of each item illustrated represents the average number eaten.

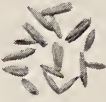

VICTORY OATS

(Avers sotiva)

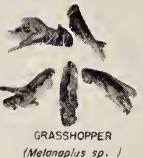

(Melonoplus so.

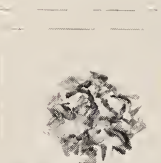

SHEPHERDS PURSE SEED ROO (Gapselta burso-postaris)

HEPHERDS PURSE

(copsella bursa-oostoris)

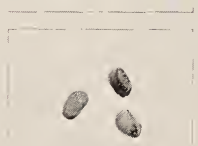

BEANS

(Phaseolus vulgaris)

(Pisum sotrom)

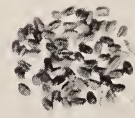

WHEAT

Triticum aestivum 
FOOD ITEMS FOR AUGUST

Food items which comprise one percent or more by number, weight or volume of the average day's food for a ring-neck pheasant in the Yellowstone and Big Horn River Valleys, Montana. The number of each item illustrated represents the average number eaten.

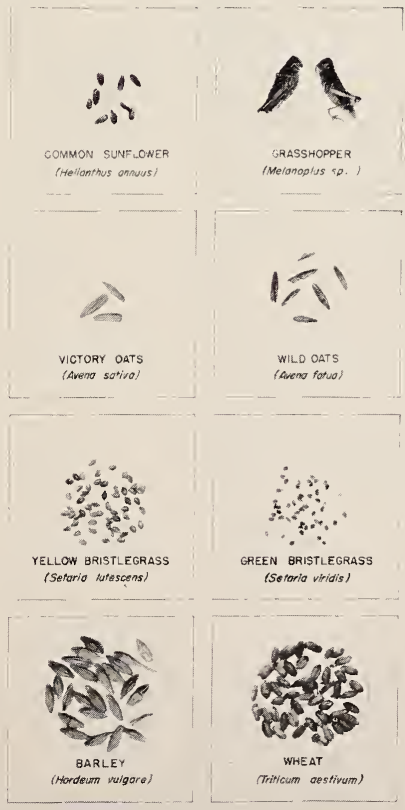




\section{FOOD ITEMS FOR SEPTEMBER}

Food items which comprise one percent or more by number, weight or volume of the average day's food for a ring-neck pheasant in the Yellowstone and Big Horn River Valleys, Montana. The number of each item illustrated represents the average number eaten.

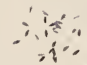

PRICKLY SOW THISTLE

(Sonchus asper)

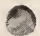

CORN

(Zeo mays)

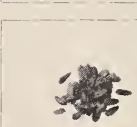

COMMON SUNFLOWER (Helianthus annusus)

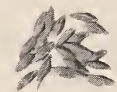

BARLEY (Mordoum vulgare)

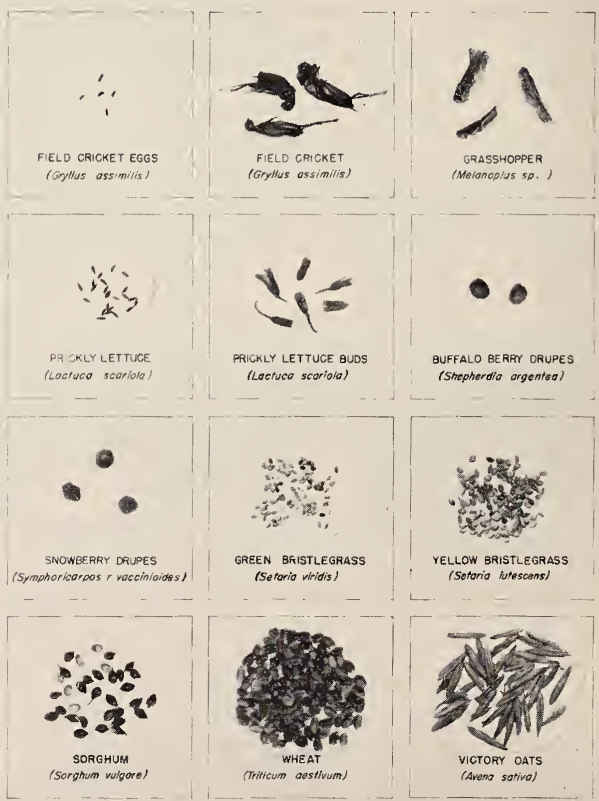


FOOD ITEMS FOR OCTOBER

Food items which comprise one per cent or more by number, weight or volume of the average day's food for a ring-neck pheas ant in the Yellowstone and Big Horn River Valleys, Montana. The number of each item illustrated represents the average number eaten.

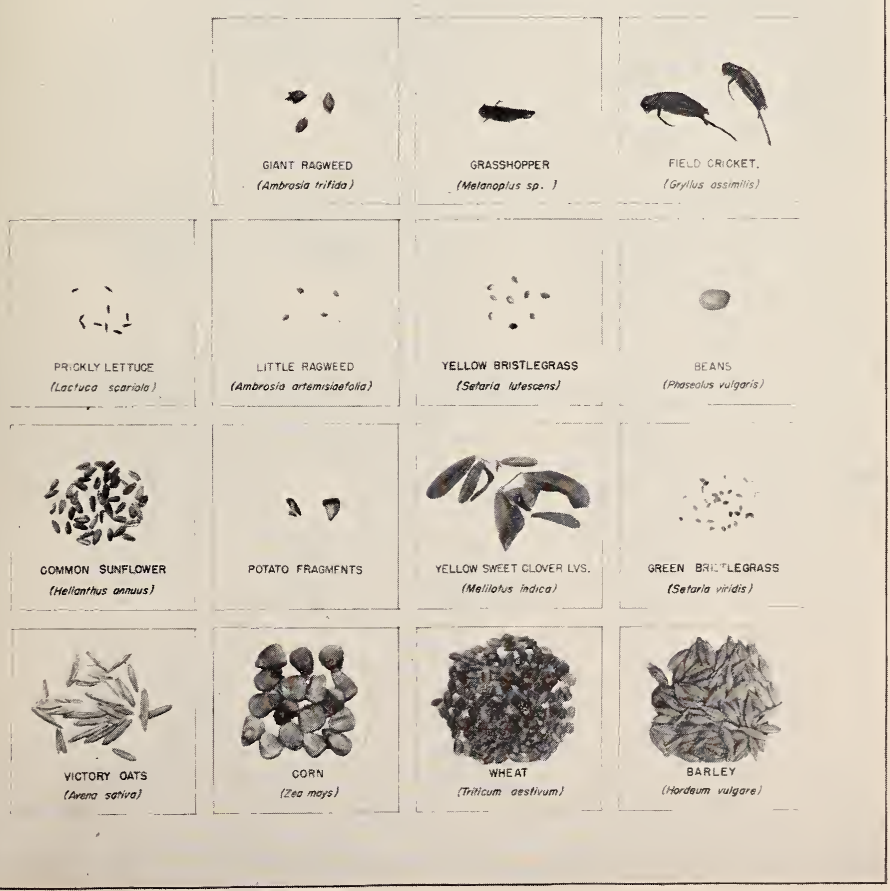


Food items which comprise one percent or more by number, weight or volume of the average day's food for a ring-neck pheasant in the Yellowstone and Big Horn River Valleys, Montona. The number of each item illustrated represents the average number eaten.
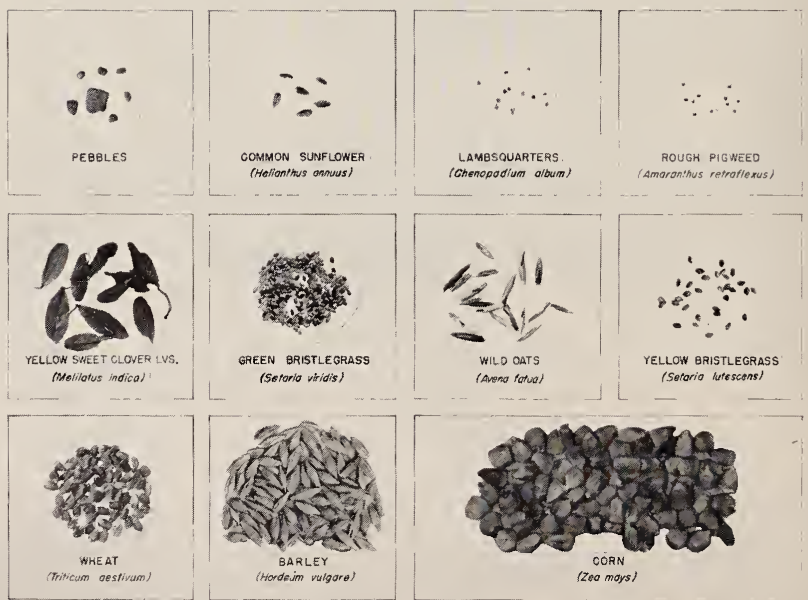
FOOD ITEMS FOR DECEMBER

Food items which comprise one percent or more by number, weight or volume of the average day's food for a ring-neck pheas ant in the Yellowstone and Big Horn River Valleys, Montana. The number of each item illustrated represents the average number eaten.
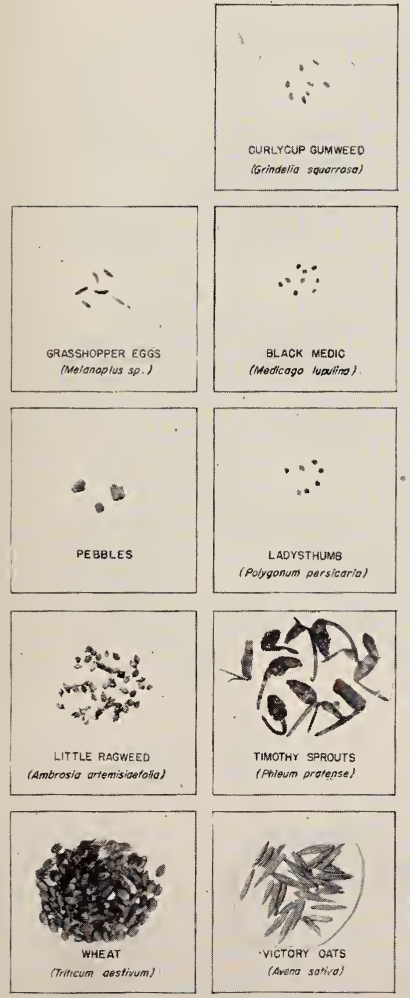
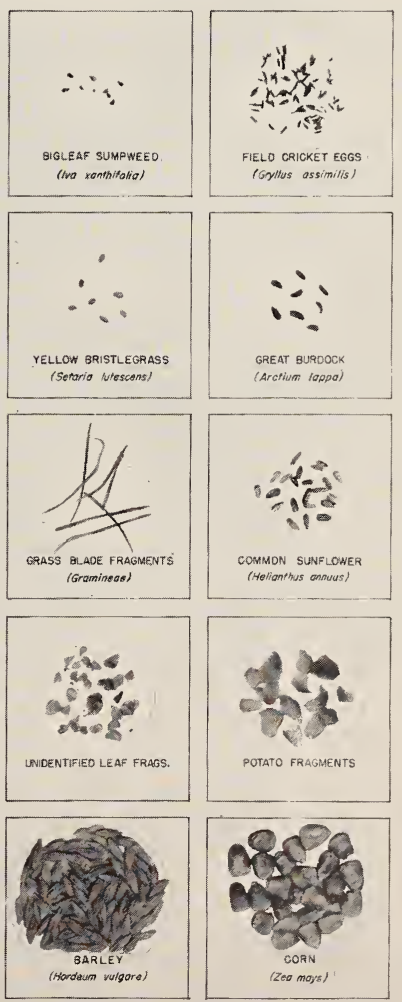
Food items which comprise one per cent or more by number, weight or volume of the average day's food for a ring-necked pheasant during the annual cycle in the Yellowstone and Big Horn River Valleys, Montana. The number of each item illustrated represents the average number eaten.
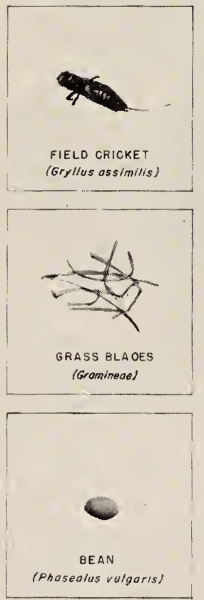

SHEPHERDS PURSE (Copsella bursa-pastaris.

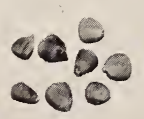

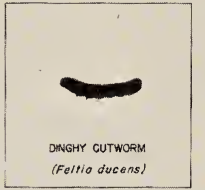
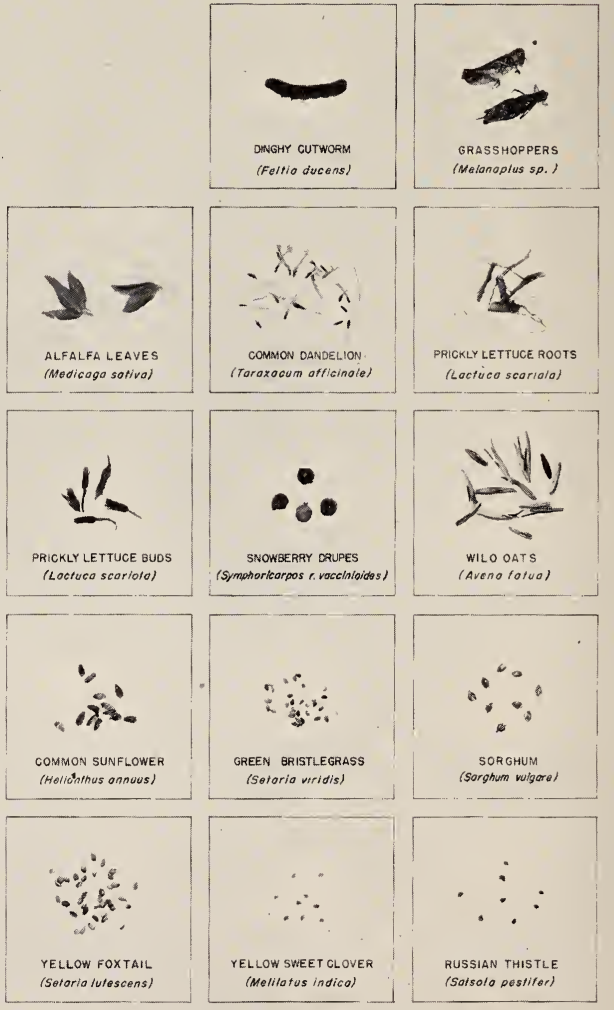

(Seloria lutescens)

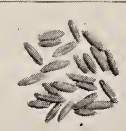

OATS

(Aveno saffva)

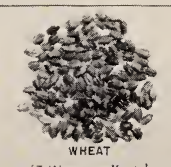

(Triticum oestivum)

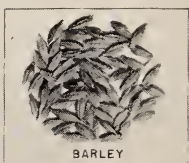

(Hordeum vulgore) 
Cultivated crops.-The proportions of the various types of cultivated crops consumed are shown in table 7 . These data seem to indicate that the pheasant is a considerable financial drain on the farmer, but it is pointed out later that the bulk of the cultivated crop types consumed are derived chiefly from field waste. Wheat (Triticum aestivum) and barley (Hordeum vulgare) are the two most important grains in the diet of pheasants in this locality. However, both corn (Zea mays) and oats (Avena sativa) rank higher than does wild oats (Avena fatua), the most commonly eaten wild seed. By comparison with other studies reported in the literature, it is clear that these proportions will vary greatly in different localities depending upon the type of farming and kinds of food available. Most other studies report that corn is by far the leading dietary item, while Cowan (5) describes the food of pheasants in truck farming areas as consisting predominantly of wild seeds. It seems apparent then that if less waste grain were available, many more weed seeds would be consumed. The monthly fluctuation in the consumption of grain is presented in tables 8,9 and 10 . 


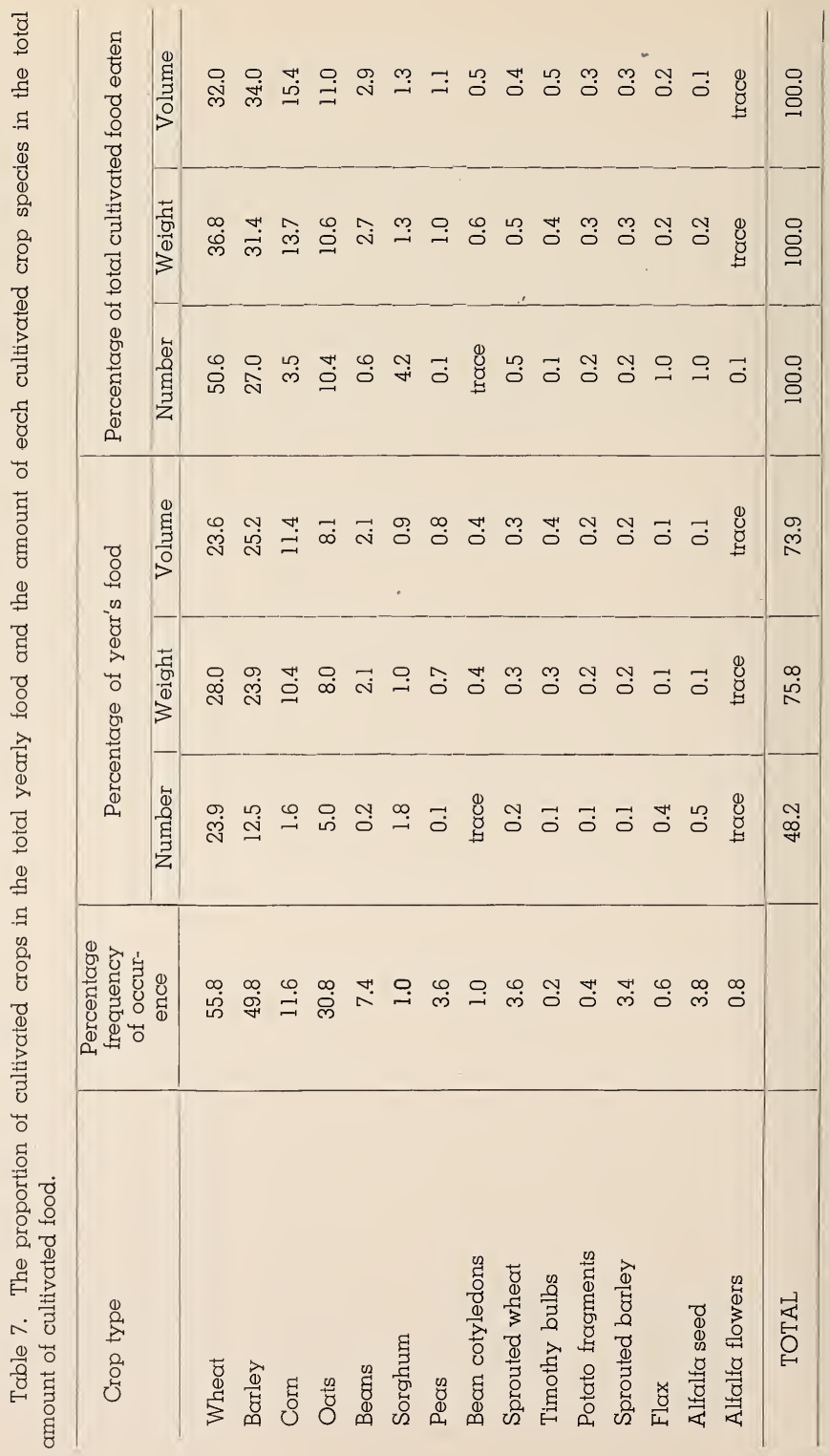


Table 8. A numerical analysis of the species of cultivated crops in the total food consumed expressed in percentage for each month.

\begin{tabular}{l|r|r|r|r|r|r|r|r}
\hline \multicolumn{1}{c|}{ Month } & Wheat & Barley & Corn & Oats & Beans & Sorghum & Other & $\begin{array}{l}\text { Totals, all } \\
\text { cultivated } \\
\text { crops }\end{array}$ \\
\hline January & \multicolumn{1}{|c|}{23.3} & 8.7 & 0.9 & 16.1 & 0.1 & - & 3.8 & 52.9 \\
February & 22.5 & 13.5 & trace & 0.9 & 0.4 & 1.5 & 5.2 & 44.0 \\
March & 33.0 & 16.2 & trace & 10.1 & 0.6 & 4.5 & 1.0 & 65.4 \\
April & 16.4 & 3.5 & 0.1 & 0.2 & - & - & trace & 20.2 \\
May & 20.2 & 10.3 & 1.4 & 8.3 & trace & - & 0.4 & 40.6 \\
June & 29.8 & 16.9 & 1.0 & 3.5 & trace & - & 4.3 & 55.5 \\
July & 19.3 & 14.2 & - & 5.2 & 0.9 & - & 1.5 & 41.2 \\
August & 23.4 & 11.5 & - & 1.6 & - & - & 0.4 & 36.9 \\
September & 19.7 & 3.6 & trace & 7.3 & trace & 6.0 & trace & 36.6 \\
October & 33.2 & 21.4 & 4.3 & 6.9 & 1.6 & - & trace & 67.4 \\
November & 9.2 & 18.5 & 14.4 & trace & - & - & 0.3 & 42.4 \\
December & 19.1 & 16.3 & 4.2 & 4.8 & 0.1 & - & 4.9 & 49.4 \\
Average & 22.4 & 12.9 & 2.2 & 5.4 & 0.3 & 1.0 & 1.8 & 46.0 \\
\hline
\end{tabular}

Table 9. A weight analysis of the species of cultivated crops in the total food consumed expressed in percentage for each month.

\begin{tabular}{l|r|r|r|r|r|r|r|r}
\hline \multicolumn{1}{|c|}{ Month } & Wheat & Barley & Corn & Oats & Beans & Sorghum & Other & $\begin{array}{l}\text { Totals, all } \\
\text { cultivated } \\
\text { crops }\end{array}$ \\
\hline January & 35.3 & 16.2 & 6.6 & 22.7 & 0.9 & - & 1.1 & 82.8 \\
February & 30.5 & 27.6 & 0.2 & 1.3 & 6.2 & 1.3 & 1.5 & 68.7 \\
March & 27.7 & 34.9 & 0.1 & 12.5 & 5.4 & 3.8 & 0.3 & 84.7 \\
April & 47.7 & 10.8 & 1.1 & 0.3 & - & - & trace & 59.6 \\
May & 23.4 & 16.8 & 11.7 & 10.0 & 0.1 & - & 4.2 & 66.2 \\
June & 32.4 & 29.7 & 3.2 & 5.6 & 0.4 & - & 5.6 & 77.6 \\
July & 32.3 & 28.9 & - & 7.3 & 13.1 & - & 5.7 & 87.3 \\
August & 36.7 & 26.0 & 0.1 & 1.7 & 1.2 & - & 5.0 & 70.7 \\
September & 36.2 & 11.0 & 1.0 & 10.0 & 0.2 & 3.8 & 0.6 & 62.8 \\
October & 30.2 & 28.2 & 20.7 & 6.3 & 0.8 & - & trace & 86.2 \\
November & 8.1 & 27.8 & 55.3 & trace & - & - & - & 91.2 \\
December & 21.7 & 27.4 & 22.0 & 5.2 & 1.8 & - & 13.1 & 91.2 \\
Average & 30.2 & 23.8 & 10.2 & 6.9 & 2.5 & 0.7 & 3.1 & 77.4 \\
\hline
\end{tabular}


Table 10. A volumetric analysis of the species of cultivated crops in the total food consumed expressed in percentage for each month.

\begin{tabular}{l|r|r|r|r|r|r|r|r}
\hline \multicolumn{1}{c|}{ Month } & Wheat & Barley & Corn & Oats & Beans & Sorghum & Other & $\begin{array}{l}\text { Totals, all } \\
\text { cultivated } \\
\text { crops }\end{array}$ \\
\hline January & \multicolumn{1}{|c|}{31.5} & 18.1 & 7.7 & 20.2 & 0.9 & - & 1.2 & 79.6 \\
February & 24.7 & 27.9 & 0.3 & 1.3 & 5.9 & 1.1 & 1.3 & 62.7 \\
March & 23.5 & 37.0 & 0.1 & 12.7 & 5.4 & 3.5 & 0.2 & 82.4 \\
April & 43.8 & 12.5 & 1.3 & 0.4 & - & - & trace & 57.9 \\
May & 20.4 & 17.6 & 12.3 & 10.0 & 0.1 & - & 3.2 & 64.7 \\
June & 28.4 & 32.2 & 3.6 & 5.8 & 0.4 & - & 5.8 & 76.7 \\
July & 28.7 & 32.1 & - & 7.8 & 13.7 & - & 5.9 & 88.2 \\
August & 32.3 & 27.0 & 0.1 & 1.7 & 1.1 & - & 6.0 & 68.2 \\
September & 32.7 & 12.4 & 1.2 & 10.5 & 0.3 & 3.7 & 0.7 & 61.5 \\
October & 24.8 & 29.0 & 22.2 & 6.1 & 0.7 & - & trace & 82.8 \\
November & 6.3 & 27.5 & 57.2 & trace & - & - & trace & 91.0 \\
December & 17.5 & 27.4 & 23.1 & 5.0 & 2.4 & - & 14.8 & 90.2 \\
Average & 26.2 & 25.1 & 10.8 & 6.8 & 2.6 & 0.7 & 3.3 & 75.5 \\
\hline
\end{tabular}

Wheat and barley are present in the diet each month of the year. The large proportions of these grains consumed, other than in the planting and harvesting seasons, come from the great amount of roadside waste and from stubble fields lying fallow. The highest percentage by number of grain consumed for any one month came after harvest in October, followed closely by March which marked the period of transporting grain from warehouses to farms. Quantities of grain blown off trucks litter the road shoulders which the birds frequent. The highest percentage of grain in the diet by weight and volume appeared during November and December when other foods were less available. The low percentage in April is chiefly the result of great quantities of newly leafed-out sweet clover (Melilotus indica), chokecherry drupes (Prunus demissa) and burdock (Arctium lappa) seeds eaten.

The seasonal distribution of the various grains consumed is indicated in table 11 .

In this locality, wheat and barley are by far the most important cultivated crops consumed during all seasons. Oats numerically outrank corn in each season, but corn is in third place by weight and volume during the fall (fig. 5). Most corn is eaten during November. The greatest damage to corn should take place during planting and mid-winter. However, in May, corn constituted just 1.4 per cent by number, 11.7 per cent by weight, and 12.3 per cent by volume of the total food consumed. Since only eight kernels of corn had been sprouted, the indications are that much of it may have been field waste. In the winter, corn constituted but 0.4 per cent by number, 1.8 per cent by weight, and 2 per cent by volume of the cultivated crops eaten. 
(2)

मे

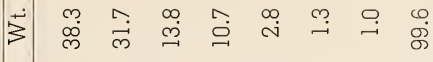

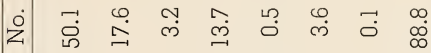

j)

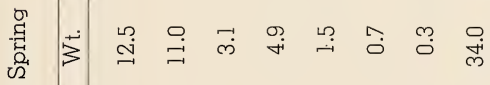

¿

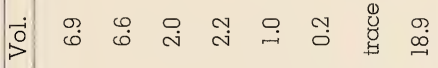

$\frac{8}{8}$

电

물

.

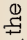

मु

Zे

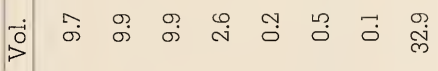

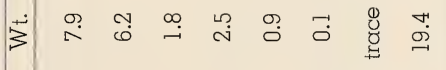

पे

范

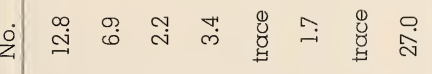

$\vec{p}$ ம்

후

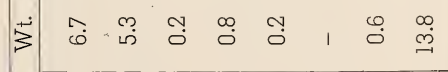

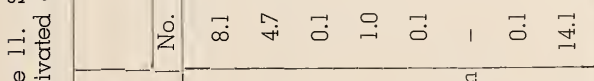

帚壱

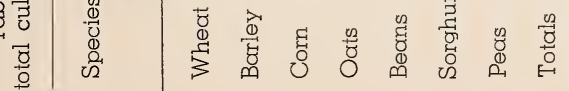


Figure 5. Seasonal fluctuations by number, weight and volume of the important cultivated crops eaten by ring-necked pheasants. Based on data appearing in Table 11.

BY NUMBER

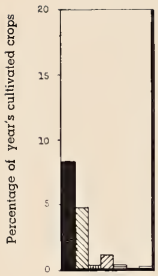

Summer

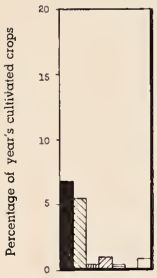

Summer

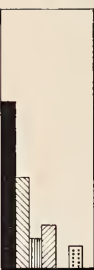

Fall

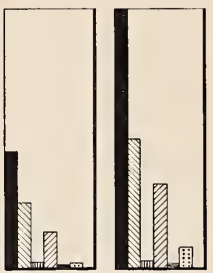

Spring

BY WEIGHT

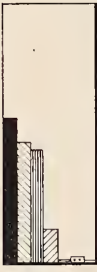

Fall

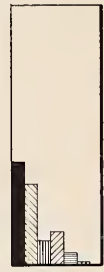

Spring

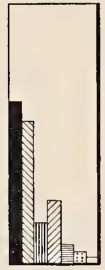

Winter

LEGEND

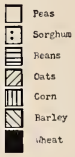

BY VOLUME

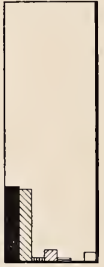

Summer

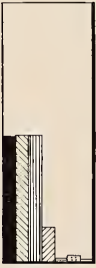

Foll

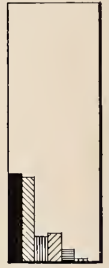

Spring

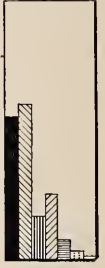

Winter

Beans (Phaseolus vulgaris) do not constitute an item of great importance in the total diet but are eaten sufficiently often in the spring to cause some concern to the farmer. The data (figure 6 and table 5, Appendix) show that the average pheasant may be expected to eat a bean cotyledon once every 3 days during the sprouting season. However, birds in proximity to bean fields at this critical time will doubtless consume a far greater number of cotyledons. Since the sprouting periods lasts for only a week or 10 days, the destruction caused by the average pheasant will not exceed 4 to 6 plants. We have no information on the amount of actual or potential damage which pheasants residing in bean fields might accomplish, but it seems reasonable to assume that such damage would reach substantial figures.

In order to diagnose more objectively food preferences of pheasants, a comparison was made between the percentage of the total land planted to certain crops and the percentage of these crop types consumed (figure 6).

At first glance it apears that strong preferences favor wheat, barley, and corn. However, all drilled grains are found in abundance at the ends of the fields. Further, most of the wheat is grown in dry land which is relatively uninhabited by pheasants. Transportation of seed grain in open trucks to and from these areas through the irrigated valleys results in great quantities of grain being blown onto the road shoulders and borrow pits. These facts indicate that, although the birds doubtless favor grains as food, this food is present in quantities in excess of what the land use figures imply. As a rule birds apparently do not seek beans or peas. Sugar beets are, insofar as this study indicates, not disturbed by the birds, although Maxon (12) states that in Col- 
Figure 6. Comparison of the amount of important cultivated crops consumed with land use. Percentages are based on the total irrigated land in the area studied and on the total amount of cultivated crop food consumed.

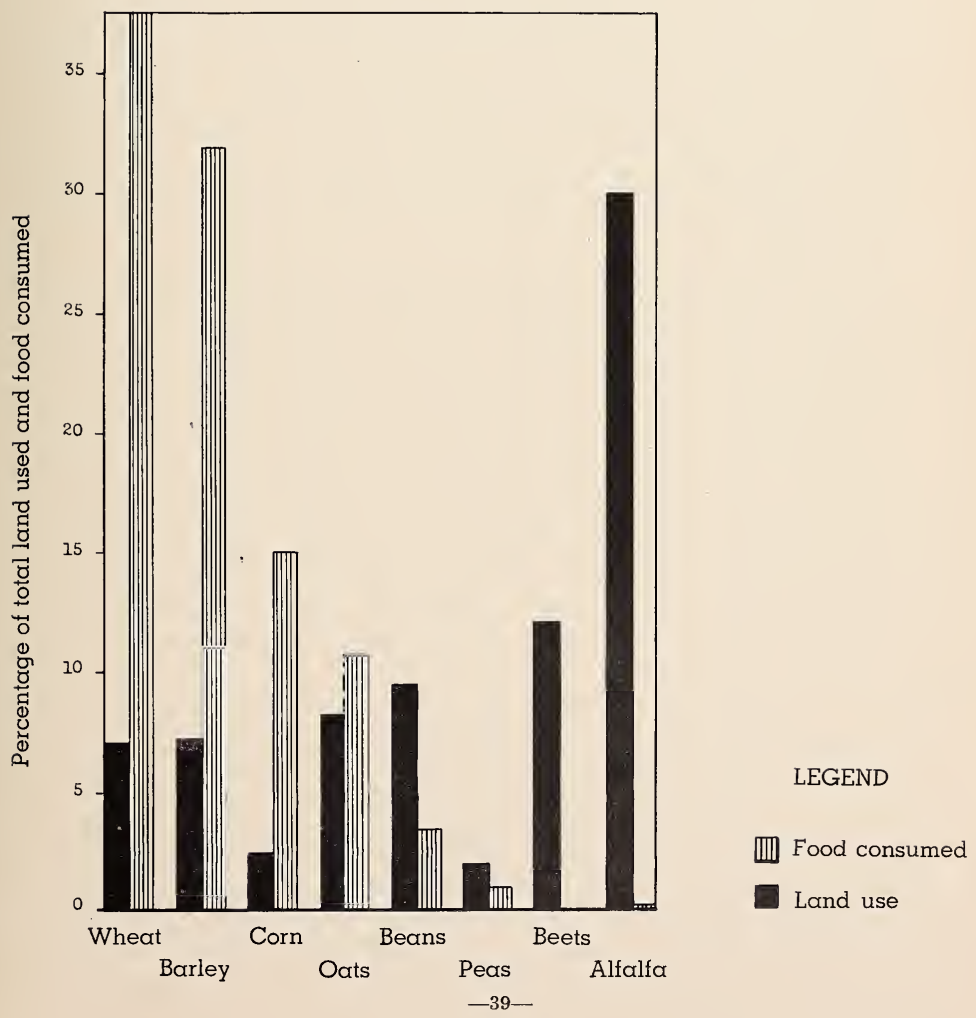


orado pheasants damage sugar beets in all stages of development. Alfalfa seed is virtually untouched.

Wild seeds.-Pheasants of the Yellowstone and Big Horn River Valleys apparently do not utilize weed seeds to the full extent of their availability. However, a significant amount of food from this source was found during all months of the year and constituted 31.3 per cent, 6.4 per cent, and 7.2 per cent of the total year's food by number, weight, and volume respectively. Table 12 summarizes pertinent data for the more important species eaten. There is considerable monthly flucutation in total weed seeds consumed; the greatest number is eaten after maturation in the late summer and fall. One bird which had eaten 900 great burdock seeds in April brought the total for that month to an abnormal high.

The seeds of bristlegrass (Setaria lutescens and S. viridis) and common dandelion (Taraxacum vulgare) made up the bulk of the weed seeds eaten from a numerical standpoint; but the larger wild oat, which composed approximately one-fifth of the seeds eaten by weight and volume, was by far the most important type consumed. Most of the 77 species of weed seeds recovered from pheasant crops appeared in amounts less than 1 per cent of the total food taken. A taxonomic list of these may be found in table 14, Appendix, and those comprising at least 1 per cent of the total monthly food consumption as well as yearly consumption are indicated in tables 1 to 13, Appendix. Although the most important weed seeds eaten during the winter are high in nutritive value (especially as a source of fat and protein to supply needed energy) grains (particularly corn, which is a very beneficial overwintering food because of its high fat and carbohydrate content), far exceed weed seeds in importance.

Green plant material. - This type of food did not constitute a very important part of the diet of the pheasants analyzed, and had an annual mean value of 6.8 per cent by number and 2.4 per cent by weight and volume. However, over half of all the crops examined contained items of this type, which seems to indicate that although their bulk consumption is insignificant they provide essential nutritional requirements. The leading types are indicated in table 13. Prickly lettuce root fragments (Lactuca scariola) which, from their appearance, had doubtlessly been cut by plowshares and subsequently eaten by approximately 1 bird in 25, made up about two-fifths by weight and nearly one-half by volume of all the green plant material consumed. Leaves of alfalfa (Medicago sativa), grass (Gramineae), prickly lettuce, and sweet clover are all consumed. Since the largest amount of foliage was eaten in May during the breeding season, it may be a seasonal dietetic requirement, but it is also true that at this time foliage of sweet clover and alfalfa is young and perhaps more palatable. The relatively great amount of plant material taken in January was undoubtedly the result of the mild fall and winter which permitted prickly lettuce plants to remain in leaf.

Wild fruits.--Other investigations have shown that the importance of fruits in the pheasant diet increases with the onset of winter and deep snow. Furthermore, Fried (9) has suggested that fruits consumed largely in winter may possibly be emergency foods; and, in this respect, Wright (18) has demonstrated that the nutritive value of some fruits commonly taken during the winter is low, with low protein and high crude fiber content. Most, however, have a high fat content and would be good energy sources, providing digestibility were high. These facts, combined with mild winter climate, may account for the comparatively few fruits eaten. Snowberries (Symphoricarpos sp.), buffalo berries (Shepherdia argentea), and wild rose hips (Rosa sp.) are available in the river bottoms and coulees. Snowberries were by far the most important of the fruits 


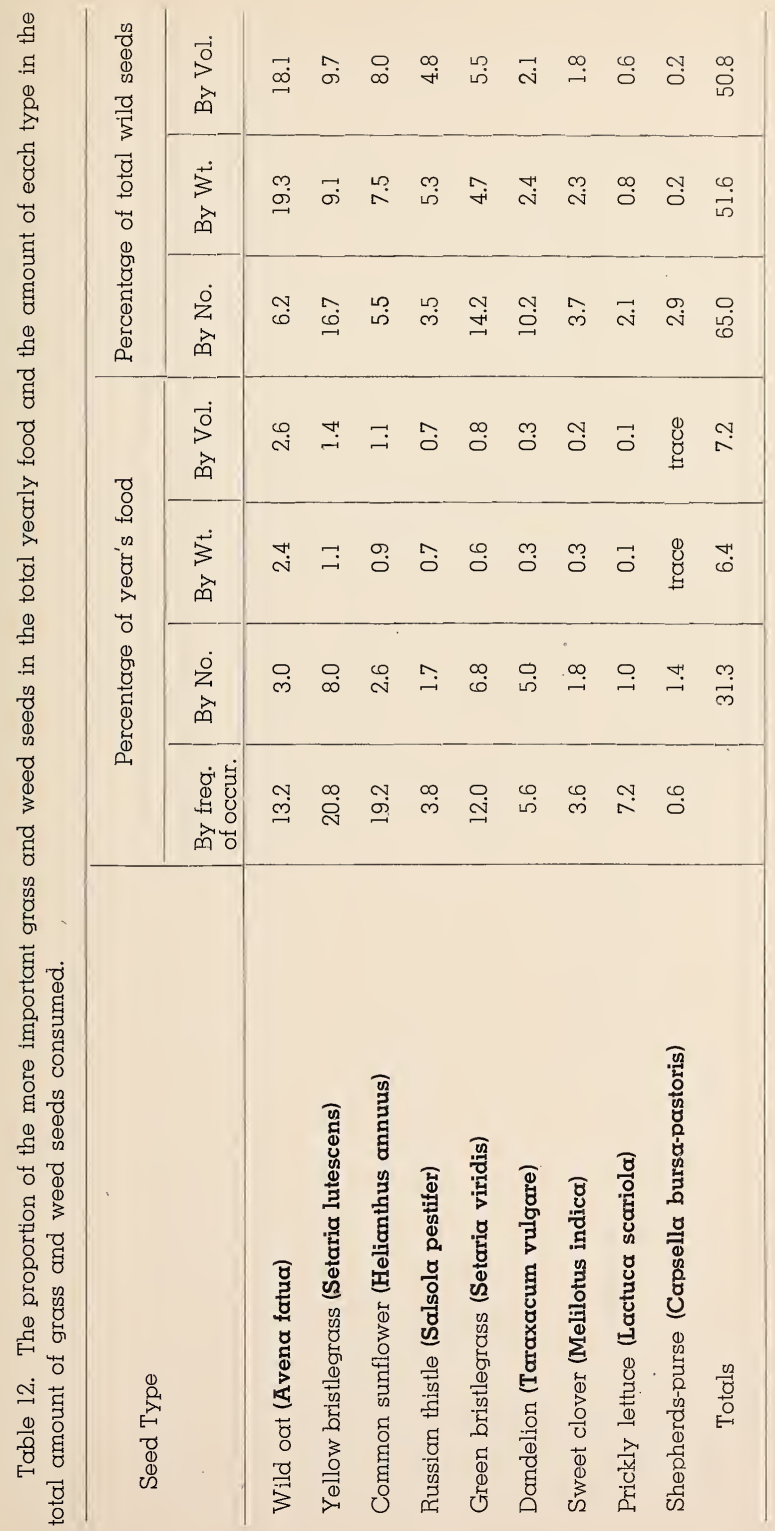




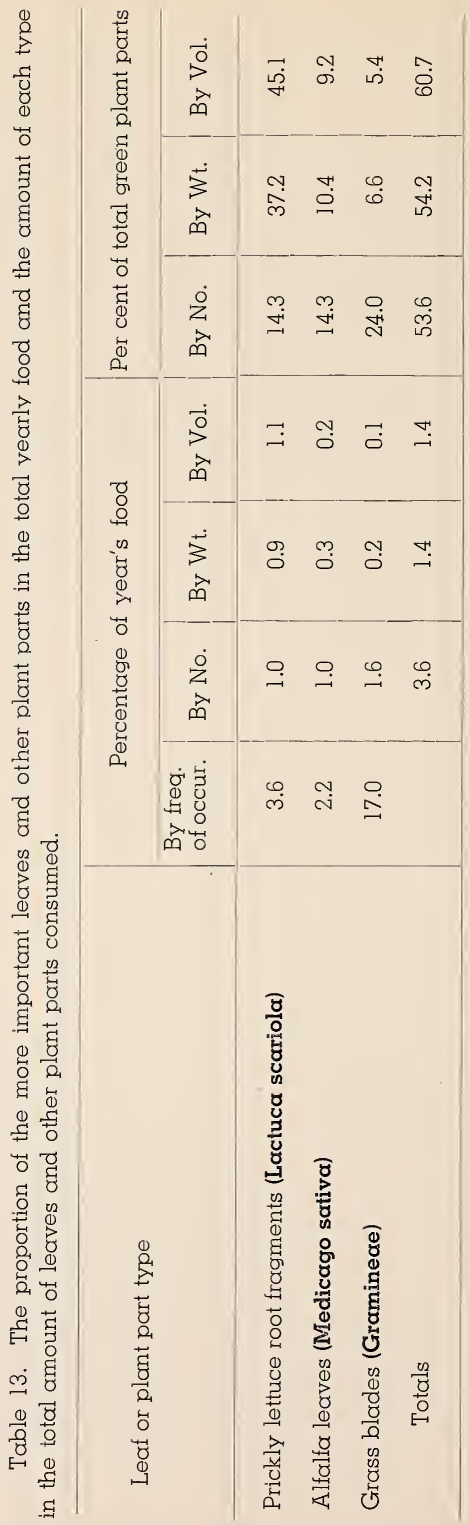




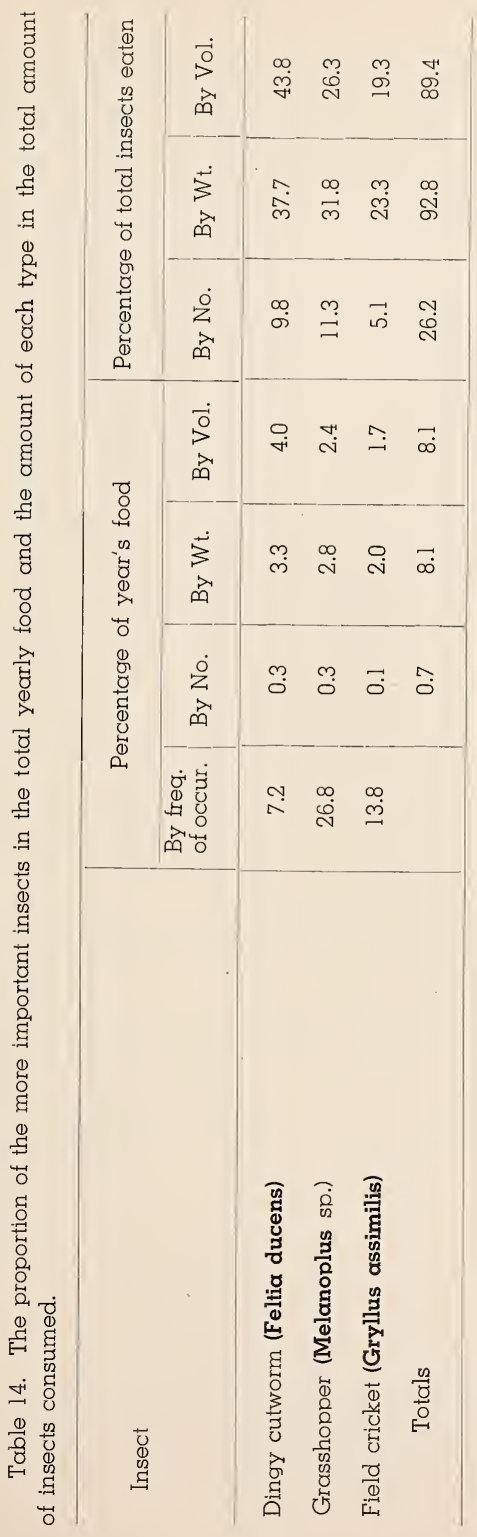


which were present in sufficient quantities to compose 1.3 per cent by number, 2 per cent by weight, and 2.7 per cent by volume of the total food consumed.

Insect food.-Sixty per cent of the pheasants examined had eaten insect food comprising 108 species, amounting to 2.8 per cent by number, 8.7 per cent by weight, and 9 per cent by volume of all food consumed. The percentage distribution of the most important insect items is shown in table 14.

Grasshoppers (Melanoplus mexicanus and M. femur-rubrum) and field crickets (Gryllus assimilis) combined to give orthopteran representatives a slight edge over lepidopteran types (cutworms), but cutworms (mostly Feltia ducens) composed the greatest individual bulk of insect types eaten. The average pheasant consumed three cutworms in 2 days during the entire annual cycle. During the cutworm season in May, the average bird took 7.5 cutworms at each meal, and as pupation time approached in June, the average pheasant ate one cutworm per meal. Data furnished by Burnett (2) reporting that cutworms were not eaten by pheasants, although they were abundant in the fields, are not generally applicable in view of the data set forth above. Moreover, Burnett's inference that pheasants are indifferent to grasshoppers is certainly not true in Montana, where during each meal in June the average bird consumed 4 nymphs, in July over 5 nymphs, in August 2 adults, in September 3 adults, and in October nearly 2 adults. Inasmuch as the pheasant feeds twice daily, these data, while not indicating a preference for grasshoppers, certainly do not suggest indifference. Moreover, those grasshoppers taken before August were not able to reproduce; therefore, the birds imposed some check on the next year's population. In winter the consumption of orthopteran eggs is significant; e.g., 93 field cricket eggs and 6 grasshopper eggs were eaten by the average pheasant during each meal in December.

During the fall months insect consumption was at its highest point, the peak coming in September. If, however, grasshopper and field cricket eggs are considered individual items, the numerical peak consumption falls in December. Insects occurred in the fewest bird crops in July and in the most crops during November. An analysis of bulk consumption by weight and volume shows that low points occurred in mid-summer and winter. Most of the insects consumed were ground-inhabiting forms, indicating that little foraging for insects in plants was undertaken.

Other animals. - The greatest amount of animal food, other than insects, was eaten in May. In this month the freshwater snails (Fossaria sp., Physella heterostropha, and Heliosoma sp.) composed 4.4 per cent, 4.2 per cent, and 2.7 per cent of the total food consumed by number, weight, and volume respectively. These snails, of which few were living, were also taken in substantial amounts during April and June. Virtually none occurred in the crops during the remainder of the year. It is of interest to note that 25 of the 27 birds which had consumed snails were hens with ovaries in an advanced stage of development. Fried (9) suggests that snails eaten during the breeding season are a ready source of calcium for the females. The present data further suggest that there is a predilection for this source of mineral requirement on the part of laying females. Earthworms, slugs, myriopods, and spiders were taken at times, in addition to snails. Snails, however, were most important.

\section{Economic Relationships of the Food and Feeding Habits}

\section{Economic Status of Food Consumed}

In tables 14 and 15, Appendix, the plant food items consumed by ringnecked pheasants in this area are grouped according to families, and the animal food items are grouped according to phyla, classes, and orders. The economic classification is placed in parentheses after each item. 
In order to assess objectively pheasant damage to agricultural crops the total monthly amounts of food in the four economic categories were computed (figure 7). Doubtful economic evaluations were placed in favor of the farmer, particularly with respect to grains during the September harvest when all grain consumed was placed in the damage category. This was done to compensate for the likelihood of feeding hogs on field waste, which, in this area, is not universally practiced. However, this period marks the only time in which the waste grains are potentially marketable, although hogs may salvage some during the winter. Most damage seems to occur during the late fall and winter months. The greatest depredation during this period involved the eating of shocked corn. Planting season damage reached its apex in June when sprouted wheat, barley, and oats were taken in amounts not exceeding 6 per cent of all the food consumed in this period. Only 8 corn seedlings were found and these were taken from three crops. Seedling damage to small grains is neglibible. However, field observations show local depredation to corn seedlings to be greater than that shown by items found in crops.

An average pheasant will consume approximately 6 grams of grain daily during September. Translated in pounds, the average pheasant will take approximately two-fifths of a pound of grain or about 2 cents worth during the entire month, provided, of course, that all waste grain consumed is salvageable by the farmer. Reliable figures indicate that 4 to 6 pounds of grain per day are required to sustain a hog. Obviously, the pheasant is not much of a financial liability from this standpoint. Annually each bird will take an average of about 12 kernels of corn daily, amounting to approximately 1 1/5 pounds per year, a scarcely significant amount. Since by far the greatest part of the annual diet is composed of items which represent waste grains, neutral food, seeds, and insects (figure 8), it is clear that the average pheasant cannot be considered detrimental to farming practices in this section of Montana. However, it is likewise apparent that pheasants concentrated in certain areas when crops are particularly vulnerable to their foraging habits are capable of damaging these crops.

\section{Results of Field Observations and Inquiries}

Few damage complaints came to the attention of the fieldman during the course of this study, notwithstanding the wide publicity given the project by personal contact, farm newsletters, and radio addresses by the County Agricultural Extension Agent.

Damage to beans was negligible during the study. Two damage claims were made, one of which even the owner admitted to be trivial, and the other was concerned with the discoloration and withering of leaves. This discoloration and withering was apparently the result of frost and not attributable to pheasants. Since it was shown previously that no particular preference toward beans as food exists, damage to this crop will probably be of little importance unless pheasants become greatly concentrated in the vicinity of bean fields.

Five farmers claimed damage to corn during the seedling period. Three of the five planted corn adjacent to heavy pheasant cover on the river bottomland. About 60 per cent of a 2-acre patch of sweet corn had been destroyed by pheasants on one of these farms. No cutworms or corn seed borers were found which indicated that the corn was not inadvertently destroyed while foraging for these pests. Small craters were present where each seedling had been planted. Beside each crater was the leaf and below each depression the root system was often located. Pheasants were observed to sever the leaf near the surface of the ground and to probe below the surface for the kernel which was pulled. The roots were generally left intact in the ground. Another 
Figure 7. Economic aspect of ring-necked pheasant foods consumed during each month of the year by frequency of occurrence, number, weight and volume.

BY FREQUENCY OF OCCURRENCE

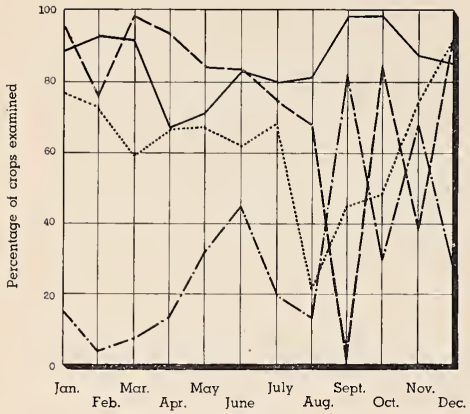

BY WEIGHT

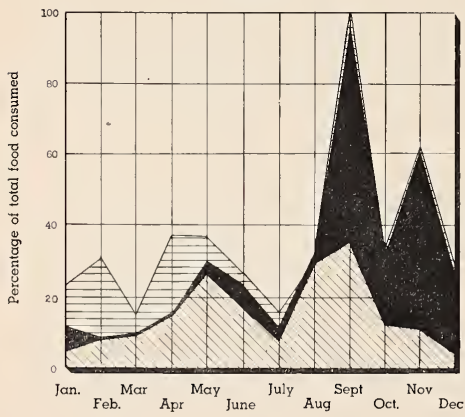

BY NUMBER

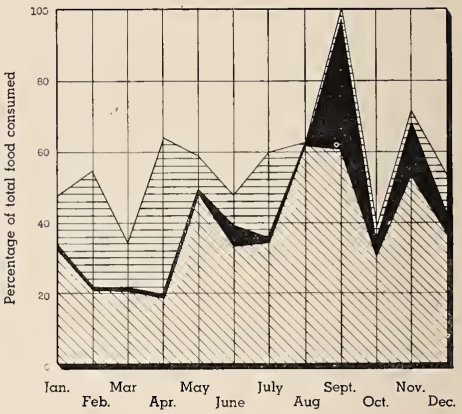

BY VOLUME

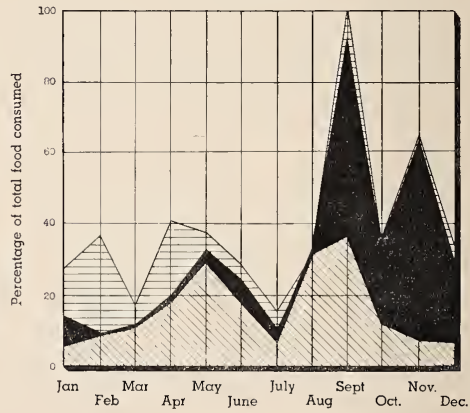

LEGEND

- Seeds and insects harmiul to crops

- Food representing crop damage

Neutral food items

Waste grains

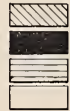


Figure 8. Economic aspect of the total food consumed by ring-necked pheasants during the year by number, weight and volume.
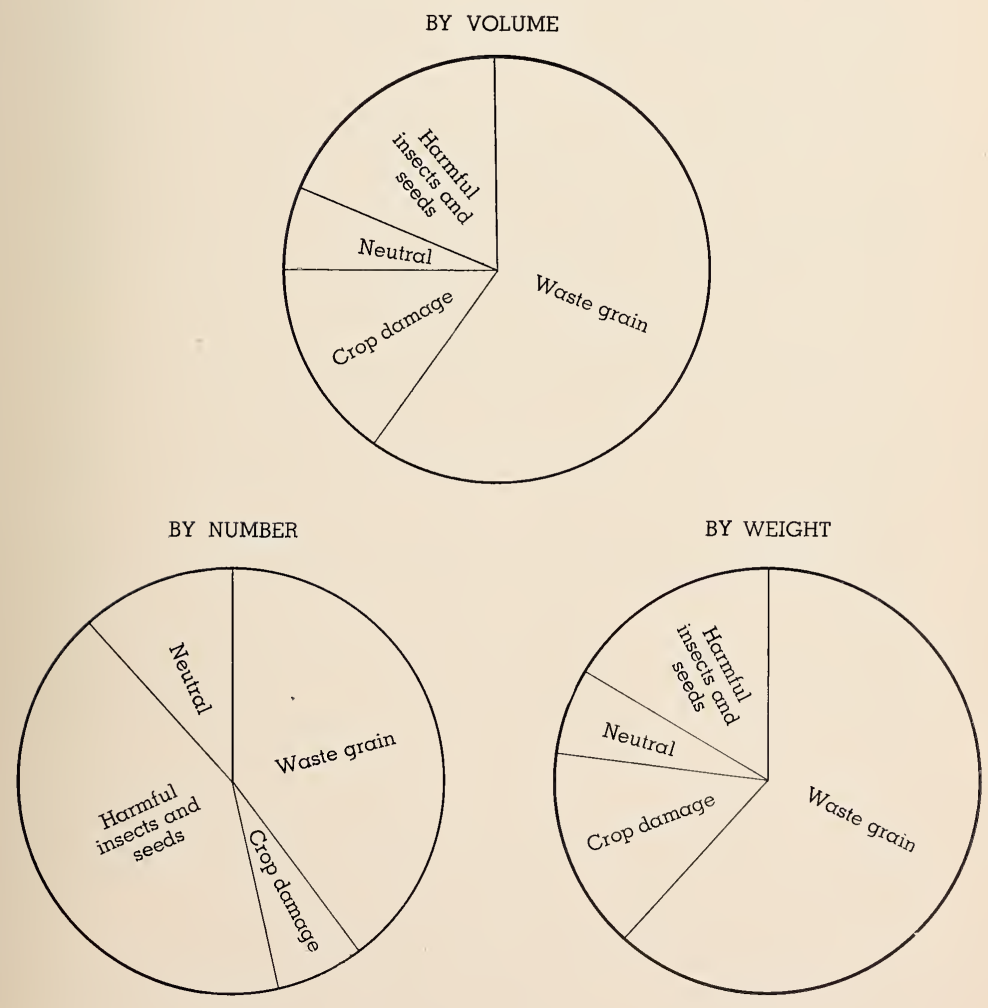
cornfield showed a blank space near an irrigation ditch. The owner stated that the ditch had broken and the 30 by 75 foot area had been flooded soon after drilling. When it was dry, pheasants foraged on it intensively. The owner concurred that the kernels had probably been washed to the surface; consequently he absolved the pheasants from blame. The outside rows of another cornfield adjacent to heavy pheasant cover were riddled by pheasants in the manner outlined above. No cutworms or corn seed borers were located here. An investigation of one farm on which damage was claimed disclosed that several corn plants were missing but only a few typical pheasant excavations were found. Numerous other holes were present but no leaf or root parts remained. Moreover, the entire field was spotted with bare areas showing no craters, and examination of these areas showed that the corn seed borer was present in the non-germinated seed. In this case the greatest damage was attributable to insect and not pheasant depredation. This corn was planted in an old alfalfa field immediately after a heavy rain. These physical conditions provided excellent opportunities for the corn seed borer. Many instances occur of damage to outer rows of corn near dense cover, and the pheasant's tendency to feed repeatedly at a favorable place points to the possibility of great local damage, especially near favorite nesting places. Washouts of seed, faulty drilling, and insect depredation probably contribute to loss to the farmer commensurate with, if not greater than, the pheasant. Although these probabilities do not alleviate the damage done by pheasants, it seems reasonable to believe that the consumption of great numbers of cutworms taken in cornfields probably more than offsets the average pheasant's damage to the crop. Investigators in Ohio, also, state that damage to corn seedlings by pheasants is considerably less than is commonly supposed (Hicks, 11).

A single claim of damage to seedling wheat was found to be negligible. A few missing seedlings and pheasant dusting areas near one side of a wheat field suggested possible pheasant activity. The damage was insignificant and the owner believed his tenant to be inclined to exaggeration. A canvass of farms selected because of land usage and proximity to pheasant cover, failed to disclose any further appreciable damage.

These field examinations seem to substantiate Hicks (11) in his contention that the pheasant has "inherited" the blame for seed losses which, for the most part, may be due to other agencies. Gigstead (10), investigating reported corn damage by pheasants in certain Wisconsin areas, found blackbirds, gray squirrels, and pocket gophers to be the chief agents of destruction. Both blackbirds and pocket gophers, in addition to crows and fieldmice, are present in vast numbers in the Montana study area. Severin (15) reported that only 4 kernels out of a total of 949 found in 71 pheasant crops in South Dakota were definitely sprouted. Fried (9) reported that 6 per cent of the corn eaten in June by Minnesota pheasants was sprouted. Both Burnett (2) and Swank (16) claimed sufficient evidence was at hand to indicate that pheasants do pull sprouted corn, while Dalke (6) reports that corn pulling is negligible in Michigan. Two conclusions may be derived from these facts: (1) Pheasants do pull seeding corn and, (2) the loss therefrom is generally insignificant, except in localized areas. The situation in the Yellowstone and Big Horn River Valleys seems to fall in line with other farming areas.

\section{Farming Methods Which Avoid Damage}

Several farming methods devised to circumvent pheasant damage have been tried with some degree of success. Carefully planned experiments with these methods have not been tested on a large scale in Montana.

Inasmuch as local damage to seedling corn is generally confined to the rows adjacent to good cover, the simplest method-and also the most success- 
ful to date in Nebraska (Mohler, 14) - is to distribute shelled or ear corn around the edges of the field just before the planted corn comes up. The amount of distributed corn required will vary of course with the density of pheasants adjacent to the field. The maximum amount of corn required in $\mathrm{Ne}$ braska was about 1 bushel per 100 rods of field border, while others prevented damage by using even less corn. In one instance a farmer who had sustained severe damage for several years tried this method and obtained complete protection by scattering a total of 3 bushels of corn around his 100 acre field. It has likewise been shown that barnyard manure distributed around the periphery of the field with a manure spreader is quite satisfactory particularly if the manure contains grain. It is of utmost importance to scatter the corn or grain just before the corn in the field comes up. If it is distributed too early it may be completely picked up before the critical time arrives and thus give no help. On the other hand the farmer should not wait until the damage occurs because preventive measures are useless then.

Another method of avoiding damage is to plant a few extra rows of corn near the nesting cover. Since pheasants habitually damage only the outer rows such a practice may prevent serious damage to the remainder of the com.

The above farming methods which avoid pheasant damage are based upon the random foraging carried on by these birds. If they find an adequate supply of preferred food along the edge of the field the chances are good that they will obtain their fill and will not molest the growing corn.

The practice of drilling corn deeper than usual to avoid pheasant damage has been tried with success in areas where the growing season is of sufficient length. The slight delay in coming through the ground has no deleterious effect on the plant. However, Montana climates may not permit such a practice.

At least two pheasant repellent treatments for corn seed have been tried with variable results. Hicks (11) reports that "Crotox" has eliminated nearly all damage from pheasants in Wood County, Ohio. The effect of "Crotox" on seed germination needs further study. Lead oxide powder as a pheasant repellent has been tried on a small scale with considerable success in Wisconsin (Chaddock, 3). This powder is cheap and easily mixed in with the seed. Initial attempts to use this repellent during this investigation in Montana proved inconclusive.

The practice in this locality of leaving corn in the fields as individual shock or in stacks through the winter is a forceful invitation to damage by pheasants. The outside ears of corn are vulnerable and considerable damage to feed corn has resulted from this practice since pheasants habitually feed at a good food source. Loss could be eliminated or minimized by fencing the stacks, by placing the corn in sheds until it is fed to livestock, or by placing the shocks as far as possible from good pheasant cover.

Grain along road shoulders represents a significant loss to farmers and incidently provides pheasants with a larae proportion of their annual food. Prior to the planting season the main road shoulders become yellow with waste grain. A $1 \frac{1}{2} 2$ foot square waste grain sample on a road shoulder was taken in May along a highway leading south from Hardin. The road shoulders were yellow for a distance of 8.4 miles. After computation for the total amount visible (not including the borrow pit) it was found that 13.39 tons of waste wheat and 440 pounds of waste barley were present. At the current market quotations, the loss sustained from wheat was $\$ 535.80$ and from barley, $\$ 6.57$. The wheat present was sufficient to seed 536 acres and the barley lost would have seeded 4 acres. Several thousand pheasants could be supported for this amount. 


\section{Beneficial Influences of Pheasants on Agriculture and the Commmunity}

No appraisal of the economic status of the ring-necked pheasant would be adequate without consideration of the direct and indirect values accruing as a result of its presence. The "meat value" of pheasant in this region is considerable, although figures are lacking to translate it into an amount per acre. However, if the cost of harvesting the pheasants is taken into account a much higher value is attained. It is this harvesting cost that is of greatest value to the community. Figures are lacking here likewise, but the average hunter is aware that his "meat value" is not comparable with his expenditures.

Every farmer is a member of a social unit and benefits in an intangible way from anything which provides additional assets to the unit. Because the study area is known widely for its excellent hunting, it attracts many nonresident sportsmen, who by purchase of transportation services, lodging, sporting goods, clothing, and other items contribute substantialiy to the prosperity of the local businessmen. In a multitude of ways the increased purchasing power ultimately reaches the man on whose land the game was raised. However, since the harvesters are not generally the same men as those on whose land the game is produced, this latter group shares but little in the direct value of the pheasants. Actually, they may suffer additional damage to their property as the result of hunter activity. At present, the sole opportunity the landowner has to share in the direct benefits derived from the birds, exclusive of their agricultural benefits, is to sell permits to hunt on this land. This practice has not evolved appreciably in this region, although in other states the practice is gaining momentum. The actual monetary return to the farmer need not be large, but it would help control the trespass problem and would yield some remuneration for the expense involved in supporting the birds throughout the year.

Consumption of weed seeds, both noxious and neutral, is not great when considered from the standpoint of total food bulk, although seeds of such noxious weeds as wild oats, yellow and green bristlegrass, and common sunflower are eaten in relatively great numbers. The seed-bearing potential of all these weeds, combined with their density in the study area, leads me to believe that the pheasant does not exert any important influence in holding in check any noxious weed. Consequently, the seed-eating habits of the pheasant have little or no positive value to the agriculturist.

Although insect consumption is below that of weed seeds, its importance to the farmer has definite positive value. While it is doubtful that pheasants consume sufficient quantities of any harmful insect species to exert an important effect on their density, it is highly probable that the consumption of cutworms is significant. Doubiless the demise of such insects with specific food habits injurious to agricultural crops diminishes potential destruction. A single cutworm is capable of destroying many corn seedlings each day. A bird which will, on the average, consume approximately eight of these larvae each meal for over a month deserves the commendation of farmers.

Additional values-direct, indirect, and intangible-accruing to the landowner as an individual have been emphasized by Miller and Powell (13), who state that the indirect values of wildlife greatly exceed the direct, and that the intangible values surmount the other two combined. As Cowan (5) suggests, many farmers enjoy seeing game on the farm. In fact, in the Montana study area most of the farmers who were interviewed considered damage by pheasants neglible and were satisfied to have the birds around; many of these provide winter food for the pheasant. Moreover, the proximity of game to farm houses aids greatly in teaching children the fundamentals of game conservation which are so necessary for the preservation of this rich heritage. 
Further, the presence of game furnishes the farmer an opportunity for business and social contacts. Many farmers eagerly await the open season in order to meet friends and to return favors to business associates. In this way, believe Miller and Powell (13), some farmers can, and often do, make wildlife on their land a business and social asset of considerable proportion.

These indirect and intangible values of game must be considered in any discussion of game economics; however, the farmer who sustains damage by wild game is not likely to appraise these values too highly. Since he cannot estimate value in "amounts per acre," which would doubtless be small, I believe that such statements as those set forth by Miller and Powell should be tempered to a greater degree.

It appears, from the information set forth in this paper, that the positive values of pheasants are at least equal to and probably outweigh the negative values, even from the standpoint of the agriculturist, whether or not he shares in the game harvest. Those who do share in the harvest secure additional direct and indirect values. Many farmers, whose farm plots are adjacent to excellent nesting cover, do sustain considerable damage from foraging birds. It is believed that these special cases can be dealt with by a liberal application of existing regulations permitting the removal of game where damage is unquestionably being done. The birds in these areas could be live-trapped during the winter and transported to other areas where they will do no harm. Such a trapping and transplanting program falls naturally in line with the work of the Wildlife Restoration Division. Since many of the farmers believe that it is incumbent upon the State to redress the wrong by undertaking to remove the pheasants, personnel of the Wildlife Restoration Division should be detailed to trap these birds.

From the standpoint of the entire community there seems little doubt that the pheasant can be considered an asset.

\section{Farmer-Sportsman Cooperation}

Perhaps the main problem associated with game damage to cultivated crops stems from the legal concept of ownership of game. Wild game is owned by the state and held in trust for the people. The only control the landowner may exert over the game he supports on his property is his right to designate who may or may not be permitted on his land. Consequently, the sportsman must assume the responsibility of maintaining rapport with the farmer. Interviews with agriculturists show that much of the ill feeling which is directed toward the pheasant is not the result of the harm the pheasant itself does, but rather to the damage that is done by the thoughtless, selfish, or vicious hunter who has little or no respect for the property rights of the landowners. Farmers concur that these individuals, although they are in the minority, are responsible for the large increase in numbers of posted farms in the better hunting localities of the study area. This practice of excluding hunters serves to augment the existing pheasant population by decreasing the pheasant harvest and actually operates contrary to the wishes of the farmers, insofar as control over the pheasant population on their land is concerned. Until sportsmen are cognizant that the farms upon which they hunt are entitled to the same respect, at least, as is their own property, they may expect to find an increasing number of farmers who are losing faith in the law which protects the pheasant on the one hand and fails to protect his property on the other, and they may expect to find a steady increase in number of the ubiquitous sign "No Hunting Allowed." 


\section{Summary}

1. This investigation was designed to clarify the controversy over the relation of ring-necked pheasants to agriculture in two irrigated valleys of Montana where pheasants are especially abundant.

2. Approximately one-third of the irrigated land of the area is planted to grain, with oats leading in acreage. The remainder is planted to alfalfa, sugar beets, and crops of lesser importance. The climate is semiarid with warm summers and severe winters. Nearly three pheasants per acre occur on the farm land in the study area.

3. Food and feeding habits were analyzed both by field observation and investigation, and by crop analysis of 500 birds taken where damage to cultivated crops occurred or might occur. No attempt was made to select birds - the young were collected along with the adults. Analyses were made by frequency of occurrence, by number, by weight (dry for seeds and leaves, moist for animal food and fruits), and by volume.

4. Food items were classified in accordance with their relationship to agriculture by local authorities in the field.

5. Pheasants feed but little in the early morning, less during midday, and most just before sunset during all seasons. Crops are not always full when the pheasant goes to roost.

6. Scratching with the toes is rare, but "rooting" with the beak is common. Items eaten indicate that the birds are ground surface foragers, and seldom feed above or below the surface.

7. Pheasants rarely travel more than $1 / 4$-mile during the feeding period.

8. Feeding habits of individual birds are variable, but pheasants taken from the same foraging group consume a similar diet.

9. Vegetable constituents make up 96 per cent by number and 88 per cent by weight and volume of the total annual food. Grains, chiefly derived from field waste, lead in all food categories. Wheat and barley are most important, with corn and oats ranking lower.

10. Most corn is consumed during November and is probably obtained from newly shocked corn which is left standing in the fields during the fall and winter. Damage to seedling corn seems insignificant when based upon analyses of pheasant crops, but field investigations disclose greater damage in isolated areas near heavy nesting cover.

11. Food preferences seem apparent for wheat, barley, and corn; however, the consumption of beans and peas does not reach an amount commensurate with the amount planted. No apparent damage occurs to sugar beets or alfalfa.

12. Pheasants consume large numbers of weed seeds which compose 31 per cent, 6 per cent, and 7 per cent of the total year's food by number, weight, and volume respectively. Chief seeds eaten are wild oats, yellow and green bristlegrass, common sunflower, and Russian thistle. The effect upon the next year's crop of weeds is probably insignificant.

13. Green plant material composes a very small portion of the bulk of food consumed ( 6.8 per cent by number, and 2.4 per cent by weight and volume). Inasmuch as more than half the birds had green food in their crops, it may be an essential component of the diet. 
14. Wild fruits were not regularly consumed during the comparatively mild winter. Such abstinence suggests that fruits occupy a place in the pheasant diet chiefly as emergency food.

15. Sixty per cent of the pheasants examined had eaten insect food, the leading type of which was cutworms. The average pheasant will consume two cutworms in 3 days during the entire annual cycle, or, during the cutworm season, it will consume over seven per meal. Grasshoppers and field crickets combine to rank ahead of cutworms in the total insect bulk consumed.

16. Freshwater snails head the list of animals other than insects eaten. Laying female pheasants exhibit a distinct preference for this type of food which is rich in calcium.

17. These data indicate that during September, when all small grains are potentially marketable, the average pheasant will consume approximately 2 cents worth per month.

18. The average bird will consume approximately 12 kernels of corn daily during the year, an amount which totals about $11 / 5$ pounds per year.

19. Food items representing actual pheasant damage made up 7 per cent by number and 15 per cent by weight and volume of the total food consumption. Items representing beneficial aspects of pheasants to agriculture composed 41 per cent by number, 17 per cent by weight and 18 per cent by volume; whereas, items representing farm waste constituted 40 per cent by number, 62 per cent by weight, and 60 per cent by volume. The remaining food bulk was composed of items neutral to the agriculturist.

20. Beneficial influences of pheasants on agriculture and the agricultural community-direct, indirect, and intangible-are at least equal to and probably outweigh the negative values. Isolated areas, however, sustain considerable local damage by pheasants.

21. Local control of pheasant populations in areas where damage is reported can best be accomplished by live-trapping during the winter months. These trapped birds may then be released in more desirable areas.

22. Efforts should be made to place farmer-sportsman cooperation upon a higher level of attainment, because one of the chief objections of the farmer to the presence of pheasants is that a few thoughtless, selfish, or vicious hunters exhibit little or no respect for the property rights of the landowner. Until this type of "sportsman" is eliminated and until the laws permit greater control by the farmer over trespassers upon his land, little decrease in the number of posted farms may be expected.

\section{Literature Cited}

(1) Bennett, L. J. and English, P. F.

1939. The fall foods of ringneck pheasants and bob-white. Pennsylvania Game News 10 (1): 8-9 and 29.

(2) Burnett, W. L.

1921. A study of the food habits of the ring-necked pheasant in Colorado. Col. Agr. Col. Cir. 31: 5-21 and 31.

(3) Chaddock, T. T.

1941. An effective pheasant repellent. Wis. Conserv. Bul. 6 (8): $46-47$.

(4) Cottam, C.

1929. The status of the ringneck pheasant in Utah. Condor 31 (3): 117-123. 
(5) Cowan, I. M.

1942. Economic status of the phasant on cultivated lands of the Okonagan Valley, British Columbia. Rpt. Brit. Columbia Game Comm. Pp. 49-63.

(6) Dalke, P. D.

1937. Food habits of adult pheasants in Michigan based on crop analysis method. Ecology 18 (2): 199-213.

(7) Davison, V. E.

1940. A field method of analyzing game bird foods. Jour. Wildlife Mangt. 4 (2): 105-116.

(8) Essig, E. O.

1929. Insects of Western North America. 1035 pp. The Macmillon Company, New York.

(9) Fried, L. A.

1940. The food habits of the ring-necked pheasant in Minnesota. Jour. Wildlife Mangt. 4 (1): 28-34.

(10) Gigstead, G.

1937. Habits of Wisconsin pheasants. Wilson Bul. 49 (1): 28-34.

(11) Hicks, L. E.

1936. Food habits of the ring-necked pheasant. Ohio Div. of Conserv. Bul. 107, 1-5.

(12) Maxson, A. C.

1921. Feeding habits and food of the ring-necked pheasant. Colo. Agr. Col. Cir. 31: 23-30.

(13) Miller, J. P. and Powell, B. B.

1942. Game and wild-fur production and utilization on agricultural land. U. S. Dept. Agr. Cir. 636, 58 pp.

(14) Mohler, L. H.

1945. Pheasants in the corn. North Dakota Outdoors 8 (2): 13-14.

(15) Severin, H. C.

1933. An economic study of the ring-necked pheasant in South Dakota. South Dakota State Col. Rpt. (Mimeographed.)

(16) Swank, W. G.

1944. Germination of seeds after ingestion by ring-necked pheasants. Jour. Wildlife Mangt. 8 (3): 223-231.

(17) Swenk, M. H.

1930. Food habits of the ring-necked pheasant in central Ne-, braska. Nebr. Agr. Expt. Sta. Res. Bul. 50, 33 pp.

(18) Wright, T. W. Jr.

1941. A study of the fall food supply of the ring-necked pheasant and the bob-white quail in Washington County, Rhode Island. Jour. Wildlife Mangt. 5 (3): 279-296. 


\section{Appendix}

Table 1. The leading pheasant food items consumed in an average meal during January.

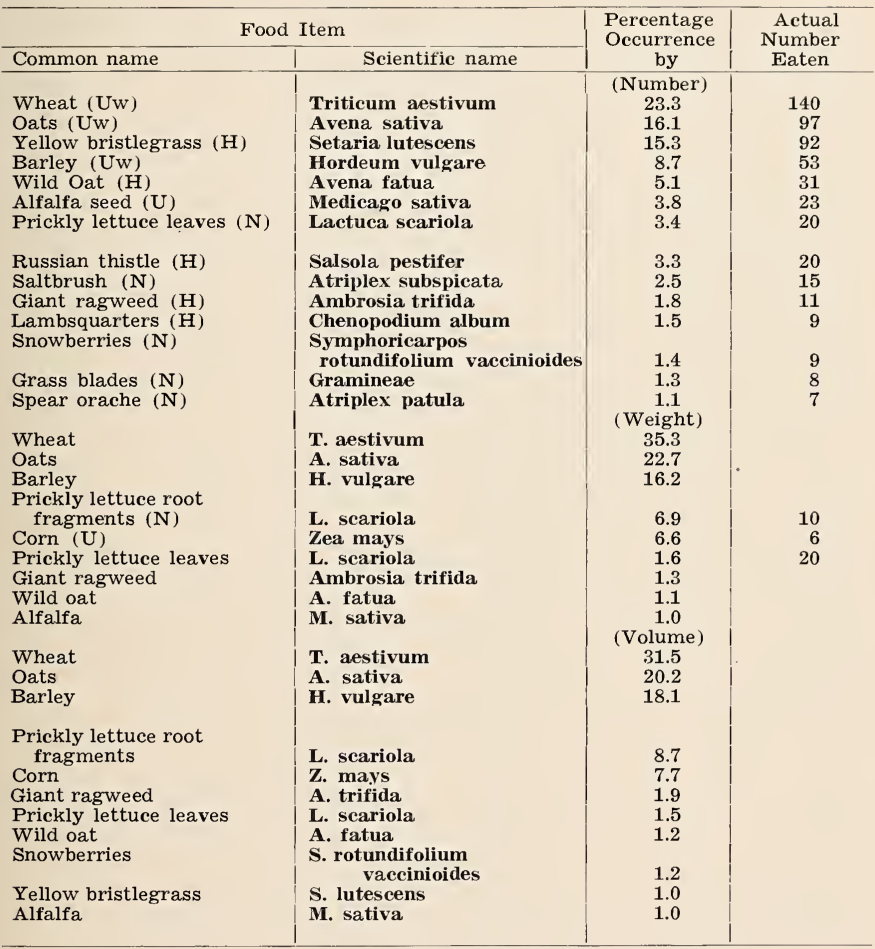


Table 2. The leading pheasant food items consumed in an average daily meal during February.

\begin{tabular}{|c|c|c|c|}
\hline \multicolumn{2}{|c|}{ Food Item } & \multirow{2}{*}{$\begin{array}{c}\text { Percentage } \\
\text { Occurrence } \\
\text { by }\end{array}$} & \multirow{2}{*}{$\begin{array}{c}\text { Actual } \\
\text { Number } \\
\text { Eaten }\end{array}$} \\
\hline Common name & Scientific name & & \\
\hline Wheat (Uw) & Triticum aestivum & $\begin{array}{l}\text { (Number) } \\
22.5\end{array}$ & 199 \\
\hline Barley (Uw) & Hordeum vulgare & 13.5 & 119 \\
\hline Grass blades (N) & Gramineae & 8.2 & 73 \\
\hline Snowberries (N) & Symphoricarpos & & \\
\hline Prickly lettuce root & rotundifolium vaccinioides & 5.9 & 52 \\
\hline fragments $(\mathrm{N})$ & Lactuca scariola & 5.9 & 52 \\
\hline Ladysthumb (H) & Polygonum persicaria & 5.6 & 50 \\
\hline Sweet clover (N) & Melilotus indica & 5.2 & 46 \\
\hline Snowberry seeds (N) & $\begin{array}{l}\text { S. rotundifolium } \\
\text { vaccinioides }\end{array}$ & 5.2 & 46 \\
\hline Flax (Uw) & Linum usitatissimum & 4.8 & 42 \\
\hline Russian thistle (H) & Salsola pestifer & 4.3 & 38 \\
\hline Beggar's tick $(\mathrm{H})$ & Bidens frondosa & 4.3 & 38 \\
\hline Wild oat $(\mathrm{H})$ & Avena fatua & 3.2 & 28 \\
\hline Spear orache $(\mathrm{N})$ & Atriplex patula & 1.9 & 17 \\
\hline Sorghum (Uw) & Soghum vulgare & 1.5 & 13 \\
\hline Small-seeded false flax $(\mathrm{H})$ & Camelina microcarpa & 1.3 & 12 \\
\hline Wheat & T aestivum & (Weight & \\
\hline Barley & H. vulgare & 27.6 & \\
\hline Snowberries & S. rotundifolium & & \\
\hline Beans (Uw) & $\begin{array}{l}\text { vaccinioides } \\
\text { Phaseolus vulgaris }\end{array}$ & $\begin{array}{r}17.9 \\
6.2\end{array}$ & 5 \\
\hline Wild oat & A. fatua & 4.6 & $J$ \\
\hline Flax & L. usitatissimum & 1.5 & \\
\hline Ladysthumb & P. persicaria & 1.4 & \\
\hline Oats (Uw) & Avena sativa & 1.3 & 8 \\
\hline Sorghum & S. vulgare & 1.3 & \\
\hline Sweet clover & M. indica & 1.1 & \\
\hline Snowberry seeds & S. rotundifolium & 1.0 & \\
\hline Russian thistle & S. pestifer & 1.0 & \\
\hline Barley & H. yulgare & (Volume) & \\
\hline Wheat & T. aestivum & 24.7 & \\
\hline Snowberries & $\begin{array}{l}\text { S. rotundifolium } \\
\text { vaccinioides }\end{array}$ & 23.6 & \\
\hline Beans & P. vulgaris & 5.9 & \\
\hline Wild oat & A. fatua & 4.7 & \\
\hline Ladysthumb & P. persicaria & 1.7 & \\
\hline Snowberry seeds & S. rotundifolium & 1.4 & \\
\hline Flax & L. usitatissimum & 1.3 & \\
\hline Oats & A. sativa & 1.3 & \\
\hline Sorghum & S. vulgare & 1.1 & \\
\hline $\begin{array}{l}\text { Sweet clover } \\
\text { Russian thistle }\end{array}$ & $\begin{array}{l}\text { M. indica } \\
\text { S. pestifer }\end{array}$ & $\begin{array}{l}1.0 \\
1.0\end{array}$ & \\
\hline & & & \\
\hline
\end{tabular}


Table 3. The leading pheasant food items consumed in an average daily meal during March.

\begin{tabular}{|c|c|c|c|}
\hline \multicolumn{2}{|c|}{ Food Item } & \multirow{2}{*}{$\begin{array}{c}\text { Percentage } \\
\text { Occurrence } \\
\text { by }\end{array}$} & \multirow{2}{*}{$\begin{array}{c}\text { Actual } \\
\text { Number } \\
\text { Eaten }\end{array}$} \\
\hline Common name & Scientific name & & \\
\hline $\begin{array}{l}\text { Wheat (Uw) } \\
\text { Barley (Uw) } \\
\text { Oats (Uw) } \\
\text { Russian thistle }(\mathrm{H})\end{array}$ & $\begin{array}{l}\text { Triticum aestivum } \\
\text { Hordeum vulgare } \\
\text { Avena sativa } \\
\text { Salsola pestifer }\end{array}$ & $\begin{array}{c}\text { (Number) } \\
33.0 \\
16.2 \\
10.1 \\
5.5\end{array}$ & $\begin{array}{r}314 \\
154 \\
96 \\
52\end{array}$ \\
\hline $\begin{array}{l}\text { Alfalfa leaf }(\mathrm{N}) \\
\text { Sorghum (Uw) } \\
\text { Grasshopper eggs and pods } \\
\text { (H) } \\
\text { Grass blades (N) } \\
\text { Sweet clover (N) } \\
\text { Patata (H) }\end{array}$ & $\begin{array}{l}\text { Medicago sativa } \\
\text { Sorghum vulgare } \\
\text { Melanoplus sp. } \\
\text { Gramineae } \\
\text { Melilotus indica } \\
\text { Monolepis nuttalliana }\end{array}$ & $\begin{array}{l}5.0 \\
4.5 \\
4.4 \\
3.3 \\
2.5 \\
2.5\end{array}$ & $\begin{array}{l}48 \\
43 \\
\\
38 \\
32 \\
24 \\
23\end{array}$ \\
\hline $\begin{array}{l}\text { Wild oat (H) } \\
\text { Spear orache }(\mathrm{N}) \\
\text { Prickley lettuce root } \\
\text { fragments (N) } \\
\text { Alfalfa (w) } \\
\text { Barley } \\
\text { Wheat } \\
\text { Oats } \\
\text { Beans (Uw) } \\
\text { Russian thistle } \\
\text { Sorghum } \\
\text { Prickly lettuce root } \\
\text { fragments } \\
\text { Wild oat } \\
\text { Alfalfa leaf } \\
\text { Grasshopper eggs and pods } \\
\text { Barley } \\
\text { Wheat } \\
\text { Oats } \\
\text { Beans } \\
\text { Russian thistle } \\
\text { Sorghum } \\
\text { Grasshopper eggs and pods } \\
\text { Prickly lettuce root } \\
\text { fragments } \\
\text { Wild oat } \\
\text { Alfalfa leaf }\end{array}$ & $\begin{array}{l}\text { Avena fatua } \\
\text { Atriplex patula } \\
\text { Lactuca scariola } \\
\text { Medicago sativa } \\
\text { H. vulgare } \\
\text { T. aestivum } \\
\text { A. sativa } \\
\text { Phaseolus vulgaris } \\
\text { S. pestifer } \\
\text { S. vulgare } \\
\text { L. scariola } \\
\text { A. fatua } \\
\text { M. sativa } \\
\text { Melanoplus sp. } \\
\text { H. vulgare } \\
\text { T. aestivum } \\
\text { A. sativa } \\
\text { P. vulgaris } \\
\text { S. pestifer } \\
\text { S. vulgare } \\
\text { Melanoplus sp. } \\
\text { L. scariola } \\
\text { A. fatua } \\
\text { M. sativa }\end{array}$ & $\begin{array}{c}1.6 \\
1.5 \\
\\
1.3 \\
1.0 \\
\text { (Weight) } \\
34.9 \\
27.7 \\
12.5 \\
5.4 \\
3.9 \\
3.8 \\
\\
2.5 \\
1.9 \\
1.7 \\
1.4 \\
\text { (Volume) } \\
37.0 \\
23.5 \\
12.7 \\
5.4 \\
4.1 \\
3.5 \\
3.1 \\
3.0 \\
2.1 \\
1.4\end{array}$ & $\begin{array}{l}16 \\
15 \\
12 \\
10\end{array}$ \\
\hline
\end{tabular}


Table 4. The leading pheasant food items consumed in an average daily meal during April.

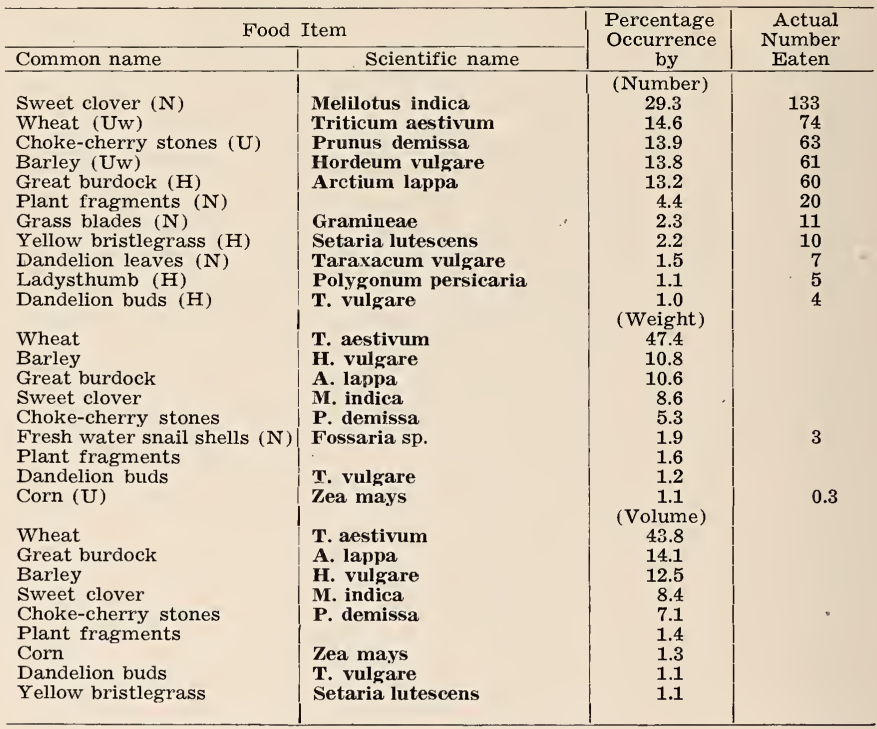


Table 5. The leading pheasant food items consumed in an average daily meal during May.

\begin{tabular}{|c|c|c|c|}
\hline \multicolumn{2}{|c|}{ Food Item } & \multirow{2}{*}{$\begin{array}{c}\text { Percentage } \\
\text { Occurrence } \\
\text { by }\end{array}$} & \multirow{2}{*}{$\begin{array}{c}\text { Actual } \\
\text { Number } \\
\text { Eaten }\end{array}$} \\
\hline Common name & Scientific name & & \\
\hline Dandelion $(\mathrm{H})$ & Taraxacum vulorare & (Number) & \\
\hline $\begin{array}{l}\text { Dandelion (H) } \\
\text { Wheat (Uw) }\end{array}$ & Taraxacum vulgare & 26.4 & 122 \\
\hline Barley (Uw) & Hordeum vulgare & $\begin{array}{l}20.1 \\
10.1\end{array}$ & 47 \\
\hline Oats (Uw) & Avena sativa & 8.2 & 38 \\
\hline Wild oat $(\mathrm{H})$ & Avena fatua & 6.4 & 29 \\
\hline Yellow bristlegrass $(\mathrm{H})$ & Setaria lutescens & 6.3 & 29 \\
\hline Wild barley $(\mathrm{H})$ & Hordeum jubatum & 4.8 & 22 \\
\hline Plantain spikes $(\mathrm{N})$ & Plantaginaceae & 3.2 & 15 \\
\hline Fresh water snail shells (N) & Physella heterostropha & 1.7 & 8 \\
\hline Dinghy cutworm $(\mathrm{H})$ & Feltia ducens & 1.6 & 7 \\
\hline Fresh water snail shells (N) & Fossaria sp. & 1.4 & 6 \\
\hline Corn (Uw) & Zea mays & 1.3 & 6 \\
\hline Sweet clover leaves (N) & Melilotus indica & 1.2 & 6 \\
\hline Prickly lettuce leaves (N) & Lactuca scariola & 1.0 & 5 \\
\hline Wheat & TT a ontivas & (Weight & \\
\hline $\begin{array}{l}\text { Wheat } \\
\text { Barley }\end{array}$ & T. aestivum & 23.4 & \\
\hline Dinghy cutworm & F. vucense & 16.9 & \\
\hline $\begin{array}{l}\text { Dinghy cutworm } \\
\text { Oats }\end{array}$ & F. ducens & 16.2 & \\
\hline Corn & A. sativa & 10.0 & \\
\hline Wild oat & 2. mays & 10.0 & \\
\hline Fresh water snail & A. ratua & 5.0 & \\
\hline $\begin{array}{l}\text { Fresn water snail } \\
\text { Bean cotyledon (U) }\end{array}$ & $\begin{array}{l}\text { Fossaria sp. } \\
\text { Phaseolus yulqaris }\end{array}$ & 2.1 & \\
\hline Dandelion & Phaseolus vulgaris & 2.0 & 0.3 \\
\hline Pea (Uw) & $\begin{array}{l}\text { T. vulgare } \\
\text { Pisum sativum }\end{array}$ & 1.2 & \\
\hline Wild barley & Pisum sativum & 1.1 & 0.5 \\
\hline $\begin{array}{l}\text { Wild barley } \\
\text { Fresh water snail shells }\end{array}$ & H. jubatum & 1.1 & \\
\hline Fresh water snail shells & Fossaria sp. & $\begin{array}{c}1.0 \\
(\mathrm{~V})\end{array}$ & \\
\hline Wheat & T. aestivum & 20.1 & \\
\hline Dinghy cutworm & F. ducens & 19.0 & \\
\hline Barley & H. vulgare & 17.4 & \\
\hline Corn & Z. mays & 10.2 & \\
\hline Oats & A. sativa & 9.8 & \\
\hline Wild oat & A. fatua & 6.2 & \\
\hline Beans & P. vulgaris & 1.9 & \\
\hline Fresh water snail & Fossaria sp. & 1.3 & \\
\hline Pea & P. sativum & 1.3 & \\
\hline Dandelion & T. vulgare & 1.2 & \\
\hline Wild barley & H. jubatum & 1.1 & \\
\hline
\end{tabular}


Table 6. The leading pheasant food items consumed in an average daily meal during June.

\begin{tabular}{|c|c|c|c|}
\hline \multicolumn{2}{|c|}{ Food Item } & \multirow{2}{*}{$\begin{array}{c}\text { Percentage } \\
\text { Occurrence } \\
\text { by }\end{array}$} & \multirow{2}{*}{$\begin{array}{l}\text { Actual } \\
\text { Number } \\
\text { Eaten }\end{array}$} \\
\hline Common name & Scientific name & & \\
\hline Wheet (Uwi) & Tritioum astivum & (Number) & \\
\hline Barley (Uw) & Triticum aestivum & 29.8 & 93 \\
\hline Wild oat $(\mathrm{H})$ & Hordeum vulgare & 17.0 & 53 \\
\hline Dandelion $(\mathrm{H})$ & Avena fatua & 14.4 & 45 \\
\hline Carp fragments $(\mathrm{N})$ & Taraxacum vulgare & 10.2 & 32 \\
\hline Sweet clover leaves (N) & Cyprinus sp. & 4.4 & 14 \\
\hline Oats (Uw) & Melilotus indica & 3.8 & 12 \\
\hline Sprouted barley (U) & Avena sativa & 3.5 & 11 \\
\hline Alfalfa leaves (N) & H. vulgare & 2.8 & $\begin{array}{llllllll}9 & & & & & \end{array}$ \\
\hline Alfalfa leaves (N) & Medicago sativa & 1.9 & 6 \\
\hline Sprouted Wheat (U) & T. aestivum & 1.6 & 5 \\
\hline Grasshopper nymphs (H) & Melanoplus sp. & 1.2 & 4 \\
\hline Alfalfa flowers (U) & M. sativa & 1.0 & 3 \\
\hline Corn (Uw) & Zea mays & 1.0 & 3 \\
\hline Leaf beetle larva $(\mathrm{H})$ & Chrysomelid sp. & 1.0 & 3 \\
\hline Wheat & T. aestivum & $\begin{array}{c}\text { (Weignt) } \\
32.2\end{array}$ & \\
\hline Barley & H. vulgare & 29.6 & \\
\hline Wild oat & A. fatua & 7.8 & \\
\hline Oats & A. sativa & 5.5 & \\
\hline Sprouted barley & H. vulgare & 3.7 & \\
\hline Corn & Z. mays & 3.1 & \\
\hline Carp fragments & Cyprinus sp. & 3.0 & \\
\hline Dinghy cutworm $(\mathrm{H})$ & F. ducens & 2.0 & 1 \\
\hline Grasshopper nymphs & Melanoplus sp. & 2.0 & \\
\hline Sprouted wheat & T. aestivum & 1.9 & \\
\hline Sweet clover leaves & M. indica & 1.4 & \\
\hline Earthworm (N) & Lumbricus sp. & 1.2 & 1 \\
\hline Dandelion & T. vulgare & 1.0 & \\
\hline & & (Volum & \\
\hline Wheat & T. aestivum & 32.2 & \\
\hline Barley & H. vulgare & 28.5 & \\
\hline Wild oat & A. fatua & 8.4 & \\
\hline Oats & A. sativa & 5.8 & \\
\hline Sprouted barley & H. vulgare & 4.1 & \\
\hline Corn & Z. mays & 3.6 & \\
\hline Carp fragments & Cyprinus sp. & 3.3 & \\
\hline Dinghy cutworm & F. ducens & $\begin{array}{l}2.0 \\
2.6\end{array}$ & \\
\hline Grasshopper nymphs & Melanoplus sp. & 1.7 & \\
\hline Sprouted wheat & T. aestivum & 1.6 & \\
\hline Sweet clover leaves & M. indica & 1.1 & \\
\hline Dandelion & T. vulgare & 1.1 & \\
\hline Earthworm & Lumbricus sp. & 1.0 & \\
\hline
\end{tabular}


Table 7. The leading pheasant food items consumed in an average daily meal during July.

\begin{tabular}{|c|c|c|c|}
\hline \multicolumn{2}{|c|}{ Food Item } & \multirow{2}{*}{$\begin{array}{c}\text { Percentage } \\
\text { Occurrence } \\
\text { by }\end{array}$} & \multirow{2}{*}{$\begin{array}{c}\text { Actual } \\
\text { Number } \\
\text { Eaten }\end{array}$} \\
\hline Common name & Scientific name & & \\
\hline $\begin{array}{l}\text { Shepherd's purse (H) } \\
\text { Wheat (Uw) } \\
\text { Shepherd's purse seed } \\
\text { capsule (N) } \\
\text { Barley (Uw) } \\
\text { Rhizostomatous bud (N) } \\
\text { Oats (Uw) } \\
\text { Grasshopper nymphs (H) } \\
\text { Wheat } \\
\text { Barley } \\
\text { Bean (Uw) } \\
\text { Oats } \\
\text { Grasshopper nymphs } \\
\text { Sprouted wheat (U) } \\
\text { Rhizostomatous bud } \\
\text { Pea (Uw) } \\
\text { Bean cotyledon (U) } \\
\text { Barley } \\
\text { Wheat } \\
\text { Beans } \\
\text { Oats } \\
\text { Grasshopper nymphs } \\
\text { Pea } \\
\text { Sprouted wheat } \\
\text { Rhizostomatous bud } \\
\text { Bean cotyledon } \\
\text { Shepherd's purse seed } \\
\text { capsule }\end{array}$ & $\begin{array}{l}\text { Capsella bursa-pastoris } \\
\text { Triticum aestivum } \\
\text { C. bursa-pastoris } \\
\text { Hordeum vulgare } \\
\text { Avena sativa } \\
\text { Melanoplus sp. } \\
\text { T. aestivum } \\
\text { H. vulgare } \\
\text { Phaseolus vulgaris } \\
\text { A. sativa } \\
\text { Melanoplus sp. } \\
\text { T. aestivum } \\
\text { Pisum sativum } \\
\text { P. vulgaris } \\
\text { H. vulgare } \\
\text { T. aestivum } \\
\text { P. vulgaris } \\
\text { A. sativa } \\
\text { Melanoplus sp. } \\
\text { Pisum sativum } \\
\text { T. aestivum } \\
\text { P. vulgaris } \\
\text { C. bursa-pastoris }\end{array}$ & $\begin{array}{c}\text { (Number) } \\
29.9 \\
19.2 \\
\\
15.4 \\
14.3 \\
6.7 \\
5.2 \\
1.6 \\
\text { (Weight) } \\
32.3 \\
28.9 \\
13.1 \\
7.3 \\
5.2 \\
2.5 \\
2.4 \\
1.8 \\
1.2 \\
\text { (Volume) } \\
32.2 \\
28.8 \\
13.7 \\
7.8 \\
4.8 \\
2.3 \\
2.2 \\
2.2 \\
1.2 \\
\\
1.1\end{array}$ & $\begin{array}{r}95 \\
62 \\
\\
50 \\
46 \\
22 \\
17 \\
5\end{array}$ \\
\hline
\end{tabular}


Table 8. The leading pheasant food items consumed in an average daily meal during August.

\begin{tabular}{|c|c|c|c|}
\hline \multicolumn{2}{|c|}{ Food Item } & \multirow{2}{*}{$\begin{array}{c}\text { Percentage } \\
\text { Occurrence } \\
\text { by }\end{array}$} & \multirow{2}{*}{$\begin{array}{c}\text { Number } \\
\text { Actual } \\
\text { Eaten }\end{array}$} \\
\hline Common name & Scientific name & & \\
\hline $\begin{array}{l}\text { Yellow bristlegrass (H) } \\
\text { Wheat (Uw) } \\
\text { Green bristlegrass (H) } \\
\text { Barley (Uw) } \\
\text { Common sunflower (H) } \\
\text { Wild oat (H) } \\
\text { Oats (Uw) } \\
\text { Wheat } \\
\text { Barley } \\
\text { Grasshopper (H) } \\
\text { Yellow bristlegrass } \\
\text { Pea (Uw) } \\
\text { Wild oat } \\
\text { Field cricket nymph (H) } \\
\text { Green bristlegrass } \\
\text { Common sunflower } \\
\text { Oats } \\
\text { Beans (Uw) } \\
\text { Wheat } \\
\text { Barley } \\
\text { Grasshopper } \\
\text { Yellow bristlegrass } \\
\text { Pea } \\
\text { Wild oat } \\
\text { Green bristlegrass } \\
\text { Common sunflower } \\
\text { Field cricket nymph } \\
\text { Oats } \\
\text { Beans }\end{array}$ & $\begin{array}{l}\text { Sectaria lutescens } \\
\text { Triticum aestivum } \\
\text { Setaria viridis } \\
\text { Hordeum vulgare } \\
\text { Helianthus annuus } \\
\text { Avena fatua } \\
\text { Avena sativa } \\
\text { T. aestivum } \\
\text { H. vulgare } \\
\text { Melanoplus sp. } \\
\text { S. lutescens } \\
\text { Pisum sativum } \\
\text { A. fatua } \\
\text { Gryllus assimilis } \\
\text { S. viridis } \\
\text { H. annuus } \\
\text { A. sativa } \\
\text { Phaseolus vulgaris } \\
\text { T. aestivum } \\
\text { H. vulgare } \\
\text { Melanoplus sp. } \\
\text { S. lutescens } \\
\text { P. sativum } \\
\text { A. fatua } \\
\text { S. viridis } \\
\text { H. annuus } \\
\text { G. assimilis } \\
\text { A. sativa } \\
\text { P. vulgaris }\end{array}$ & $\begin{array}{c}\text { (Number) } \\
27.5 \\
23.1 \\
23.0 \\
11.3 \\
4.2 \\
3.3 \\
1.6 \\
\text { (Weight) } \\
37.6 \\
26.8 \\
9.9 \\
5.9 \\
4.8 \\
3.9 \\
2.7 \\
2.4 \\
2.4 \\
1.7 \\
1.2 \\
\text { (Volume) } \\
31.8 \\
26.5 \\
8.6 \\
7.2 \\
6.0 \\
3.7 \\
3.3 \\
3.3 \\
2.4 \\
1.8 \\
1.2\end{array}$ & $\begin{array}{r}56 \\
48 \\
47 \\
23 \\
9 \\
7 \\
3\end{array}$ \\
\hline
\end{tabular}


Table 9. The leading pheasant food items consumed in an average daily meal during September.

\begin{tabular}{|c|c|c|c|}
\hline \multicolumn{2}{|c|}{ Food Item } & \multirow{2}{*}{$\begin{array}{c}\text { Percentage } \\
\text { Occurrence } \\
\text { by }\end{array}$} & \multirow{2}{*}{$\begin{array}{l}\text { Actual } \\
\text { Number } \\
\text { Eaten }\end{array}$} \\
\hline Common name & Scientific name & & \\
\hline $\begin{array}{l}\text { Yellow bristlegrass (H) } \\
\text { Wheat (U) } \\
\text { Green bristlegrass (H) } \\
\text { Oats (U) } \\
\text { Common sunflower (H) } \\
\text { Sorghum (U) } \\
\text { Prickly sow-thistle (H) } \\
\text { Prickly lettuce (H) } \\
\text { Barley (U) } \\
\text { Prickly lettuce buds (H) } \\
\text { Wheat } \\
\text { Field cricket (H) } \\
\text { Grasshopper (H) } \\
\text { Barley } \\
\text { Oats } \\
\text { Yellow bristlegrass } \\
\text { Sorghum } \\
\text { Common sunflower } \\
\text { Green bristlegrass } \\
\text { Corn (U) } \\
\text { Wheat } \\
\text { Barley } \\
\text { Field cricket } \\
\text { Oats } \\
\text { Grasshopper } \\
\text { Yellow bristlegrass } \\
\text { Sorghum } \\
\text { Common sunflower } \\
\text { Green bristlegrass } \\
\text { Corn }\end{array}$ & $\begin{array}{l}\text { Setaria lutescens } \\
\text { Triticum aestivum } \\
\text { Setaria viridis } \\
\text { Avena sativa } \\
\text { Helianthus annuus } \\
\text { Sorghum vulgare } \\
\text { Sonchus asper } \\
\text { Lactuca scariola } \\
\text { Hordeum vulgare } \\
\text { L. scariola } \\
\text { T. aestivum } \\
\text { Gryllus assimilis } \\
\text { Melanoplus sp. } \\
\text { H. vulgare } \\
\text { A. sativa } \\
\text { S. lutescens } \\
\text { S. vulgare } \\
\text { H. annuus } \\
\text { S. viridis } \\
\text { Zea mays } \\
\text { T. aestivum } \\
\text { H. vulgare } \\
\text { G. assimilis } \\
\text { A. sativa } \\
\text { Melanoplus sp. } \\
\text { S. lutescens } \\
\text { S. vulgare } \\
\text { H. annuus } \\
\text { S. viridis } \\
\text { Z. mays }\end{array}$ & $\begin{array}{c}\text { (Number) } \\
22.8 \\
19.7 \\
17.0 \\
7.3 \\
7.1 \\
6.0 \\
4.9 \\
4.4 \\
3.6 \\
1.1 \\
\text { (Weight) } \\
36.2 \\
13.1 \\
11.2 \\
11.0 \\
10.0 \\
4.4 \\
3.8 \\
2.1 \\
1.6 \\
1.0 \\
\text { (Volume) } \\
32.7 \\
12.4 \\
12.0 \\
10.5 \\
10.2 \\
5.6 \\
3.7 \\
2.7 \\
2.4 \\
1.2\end{array}$ & $\begin{array}{r}125 \\
108 \\
93 \\
40 \\
39 \\
33 \\
27 \\
24 \\
20 \\
6\end{array}$ \\
\hline
\end{tabular}


Table 10. The leading pheasant food items consumed in an average daily meal during October.

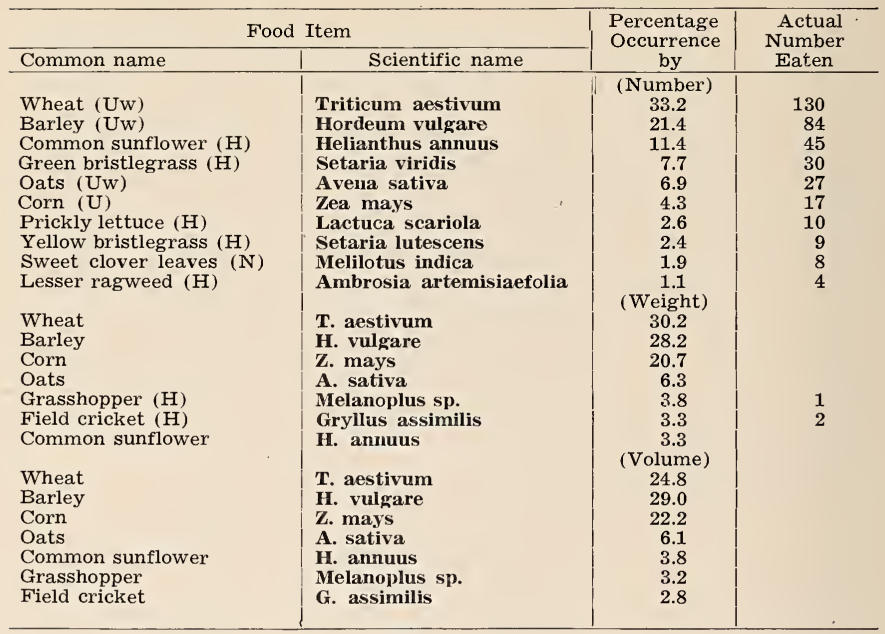

Table 11. The leading pheasant food items consumed in an average daily meal during November.

\begin{tabular}{l|l|r|r}
\hline \multicolumn{2}{c|}{ Food Item } & $\begin{array}{c}\text { Percentage } \\
\text { Occurrence } \\
\text { by }\end{array}$ & $\begin{array}{r}\text { Actual } \\
\text { Number } \\
\text { Eaten }\end{array}$ \\
\hline Common name & \multicolumn{1}{|c|}{ Scientific name } & (Number) & \\
Green bristlegrass (H) & Setaria viridis & 40.5 & 279 \\
Barley (Uw) & Hordeum vulgare & 18.5 & 128 \\
Corn (U) & Zea mays & 14.4 & 100 \\
Wheat (Uw) & Triticum aestivum & 4.2 & 64 \\
Yellow bristlegrass (H) & Setaria lutescens & 2.8 & 32 \\
Wild oat (H) & Avena fatua & 1.8 & 19 \\
Lambsquarters (H) & Chenopodium album & 1.6 & 13 \\
Rough pigweed (H) & Amaranthus retroflexus & 1.4 & 11 \\
Sweet clover leaves (N) & Melilotus indica & (Weight) & \\
& & 55.3 & \\
Corn & Z. mays & 27.8 & \\
Barley & H. vulgare & 8.1 & \\
Wheat & T. aestivum & 1.2 & \\
Green bristlegrass & S. viridis & (Volume) & \\
Wild oat & A. fatua & 62.7 & \\
Corn & Z. mays & 30.2 & \\
Barley & H. vulgare & 6.9 & \\
Wheat & T. aestivum & 4.1 & \\
Green bristlegrass & S. viridis & 1.8 & \\
Wild oat & A. fatua & & \\
& & & \\
\hline
\end{tabular}


Table 12. The leading pheasant food items consumed in an average daily meal during December.

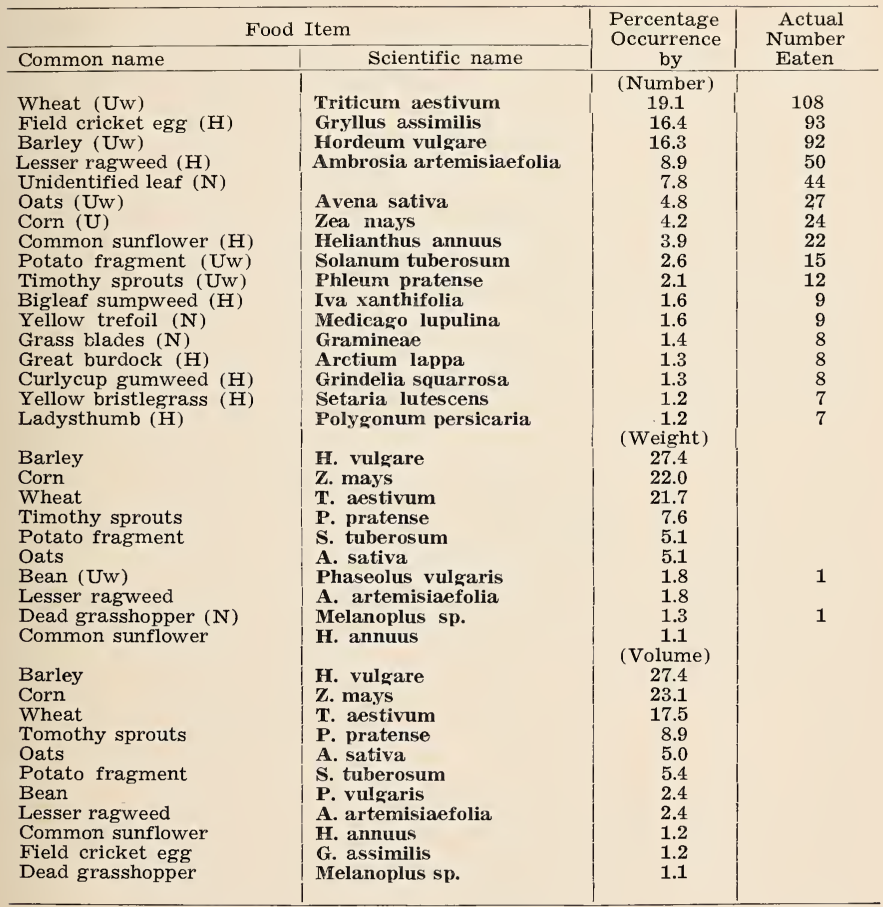


Table 13. The leading pheasant food items consumed in an average daily meal during the entire year.

\begin{tabular}{|c|c|c|c|}
\hline \multicolumn{2}{|c|}{ Food Item } & \multirow{2}{*}{$\begin{array}{c}\text { Percentage } \\
\text { Occurrence } \\
\text { by }\end{array}$} & \multirow{2}{*}{$\begin{array}{l}\text { Actual } \\
\text { Number } \\
\text { Eaten }\end{array}$} \\
\hline Common name & Scientific name & & \\
\hline & & (Number) & \\
\hline Wheat (U, Uw) & Triticum aestivum & 23.9 & 115 \\
\hline Yellow bristlegrass $(\mathrm{H})$ & $\begin{array}{l}\text { Horatam lutescens } \\
\text { Setaria lute }\end{array}$ & $\begin{array}{r}12.5 \\
8.0\end{array}$ & $\begin{array}{l}60 \\
38\end{array}$ \\
\hline Green bristlegrass (H) & Setaria viridis & $\begin{array}{l}8.0 \\
6.8\end{array}$ & $\begin{array}{l}38 \\
33\end{array}$ \\
\hline Oats (U, Uw) & Avena sativa & 5.0 & 24 \\
\hline Common dandelion $(\mathrm{H})$ & Taraxacum vulgare & 5.0 & 24 \\
\hline Wild oat $(\mathrm{H})$ & Avena fatua & 3.0 & 14 \\
\hline Common sunflower $(\mathrm{H})$ & Helianthus annuus & 2.6 & 13 \\
\hline Sorghum (U, Uw) & Sorghum vulgare & 1.8 & 9 \\
\hline Yellow sweet clover $(\mathrm{N})$ & Melilotus indica & 1.8 & 9 \\
\hline Russian thistle $(\mathrm{H})$ & Salsola pestifer & 1.7 & 8 \\
\hline Grass blades (N) & Gramineae & 1.6 & 8 \\
\hline Corn (U, Uw) & Zea mays & 1.6 & 8 \\
\hline \multicolumn{4}{|l|}{ Prickly lettuce root } \\
\hline fragments $(\mathrm{N})$ & Lactuca scariola & 1.0 & 5 \\
\hline Prickly lettuce $(\mathrm{H})$ & L. scariola & 1.0 & 5 \\
\hline Alfalfa leaf $(\mathrm{N})$ & Medicago sativa & 1.0 & 5 \\
\hline Wheat & $\mathbf{T}$, aestivum & (Weight & \\
\hline Barley & H. vulgare & 23.9 & \\
\hline Corn & Z. mays & 10.4 & \\
\hline Oats & A. sativa & 8.0 & \\
\hline Dinghy cutworm $(\mathrm{H})$ & Feltia ducens & 3.3 & 1 \\
\hline Grasshopper (H) & Melanoplus sp. & 2.8 & 2 \\
\hline Wild oat $(\mathrm{H})$ & A. fatua & 2.4 & \\
\hline Bean $(U, U w)$ & Phaseolus vulgaris & 2.1 & 1 \\
\hline Field cricket $(\mathrm{H})$ & Gryllus assimilis & 2.0 & 1 \\
\hline \multirow[t]{2}{*}{ Snowberry drupe (N) } & Symphoricarpos & & \\
\hline & rotundifolius vaccinioides & 1.8 & 4 \\
\hline Yellow bristlegrass & S. lutescens & $\begin{array}{c}1.1 \\
\text { (Volume) }\end{array}$ & \\
\hline Wheat & T. aestivum & 23.6 & \\
\hline Barley & H. vulgare & 25.2 & \\
\hline Corn & Z. mays & 11.4 & \\
\hline Oats & A. sativa & 8.1 & \\
\hline Dinghy cutworm & F. ducens & 4.0 & \\
\hline Wild oat & A. fatua & 2.6 & \\
\hline \multirow[t]{2}{*}{ Snowberry drupe } & S. rotundifolius & & \\
\hline & vacciniojdes & 2.5 & \\
\hline $\begin{array}{l}\text { Brassiopper } \\
\text { Bean }\end{array}$ & $\begin{array}{l}\text { Melanoplus sp. } \\
\text { P. vulgaris }\end{array}$ & 2.4 & \\
\hline Field cricket & G. assimilis & 1.7 & \\
\hline Yellow bristlegrass & S. lutescens & 1.4 & \\
\hline \multirow{3}{*}{$\begin{array}{l}\text { Common sunflower } \\
\text { Prickly lettuce root } \\
\text { fragments }\end{array}$} & H. annuus & 1.1 & \\
\hline & & & \\
\hline & L. scariola & 1.1 & \\
\hline
\end{tabular}


Table 14. A taxonomic list of the plant food items found in the crops of 500 ring-necked pheasants analyzed during this study.

Cypress family (Cupressaceae)

Juniper cone (Juniperus scopulorum) (N)

Grass family (Gramineae)

Grass leaves (N)

Meadow fescue (Festuca elatior) (U)

Downy brome (Bromus tectorum), (H)

Cheat grass (Bromus secalinus) $(\mathrm{H})$

Smooth brome (Bromus inermis) (H)

Brome grass (Bromus sp.) (H)

Perennial ryegrass (Lolium perenne) (N)

Slender wheatgrass (Agropyron pauciflorum) (U)

Wheatgrass (Agropyron sp.) (U)

Wheat (Triticum aestivum) (U, Uw)

Wild barley (Hordeum jubatum) (H)

Wild barley (Hordeum pusillum) $(\mathrm{H})$

Barley (Hordeum vulgare) (U, Uw)

Wild oat (Avena fatua) $(\mathrm{H})$

Oats (Avena sativa) (U, Uw)

Timothy (Phelum pratense) (U, Uw)

Yellow bristlegrass or foxtail (Setaria lutescens) $(\mathrm{H})$

Green bristlegrass or foxtail (Setaria viridis) $(\mathrm{H})$

Barnyard grass (Echinochloa crusgalli) (H)

Witchgrass (Panicum capillare) $(\mathrm{H})$

Fall panicum (Panicum dichotomiflorum) (N)

Sorghum (Sorghum vulgare) (U, Uw)

Corn (Zea mays) (U, Uw)

Sedge family (Cyperaceae)

Bulrush (Scirpus sp.) (N)

Sedge (Carex sp.) (N)

Lily family (Liliaceae)

Wild onion (Allium sp.) (N)

Buckwheat family (Polygonaceae)

Common knotweed (Polygonum lapathifolium) (H)

Bigseed ladysthumb (Polygonum pennsylvanicum) (H)

Ladysthumb (Polygonum persicaria) (H)

Smartweed (Polygonum hydropiper) $(\mathrm{H})$

Black bindweed (Polygonum convolvulus) $(\mathrm{H})$

Curly dock (Rumex crispus) (H)

Dock (Rumex sp.) (H)

Goosefoot family (Chenopodiaceae)

Lambsquarters (Chenopodium album) $(\mathrm{H})$

Chenopodium hybridum $(\mathrm{H})$

Patata (Monolepis nuttalliana) (H)

Spear orache (Atriplex patula) (N)

Saltbrush Atriplex subspicata) (N)

Saltbrush (Atriplex sp.) (N)

Greasewood (Sarcobatus sp.) (H)

Russian thistle (Salsola kali tenuifolia) $(\mathrm{H})$

Seepweed (Dondia depressa) $(\mathrm{H})$

Amaranth family (Amaranthaceae)

Rough pigweed (Ämaranthus retroflexus) (H)

Tumbleweed (Amaranthus graecizans) (H)

Spreading amaranth (Ämaranthus blitoides) (H) 
Pink family (Caryophyllaceae)

Chickweed (Cerastium sp.) (H)

Common chickweed (Stellaria media) (H)

Soapwort (Saponaria vaccaria) $(\mathrm{H})$

Buttercup family (Ranunculaceae)

Buttercup (Ranunculus sp.) (N)

Caper family (Capparidaceae)

Rocky Mountain bee plant (Cleome serrulata) (H)

Mustard family (Cruciferae)

Charlock (Brassica arvensis) (H)

Pennycress (Thlaspi arvense) (H)

Shepherds-purse (Capsella bursa-pastoris) (H)

Peppergrass (Lepidium apetalum) (H)

False flax (Camelina sativa) (H)

Small-seeded false flax (Camelina microcarpa) (H)

(Cruciferce sp.) (H)

Rose family (Rosaceae)

Wild rose (Rosa sp.) (H)

Western chokecherry (Prunus demissa) (N)

Pea family (Leguminosae)

Alfalfá (Medicago sativa) (U, Uw)

Black medic (Medicago lupulina) (N)

Yellow sweet clover (Melilotus indica) (N)

Red clover (Trifolium pratense) (U)

Spanish clover (Lotus americanus) (N?)

Rattleweed (Astragalus sp.) (N)

Narrowleaf vetch (Vicia angustifolia) (N)

Peas (Pisum sativum) (U, Uw)

Beans (Phaseolus vulgaris) (U, Uw)

Flax family (Linaceae)

Linum digynum $(\mathrm{H}$ ?)

Flax (Linum usitatissimum) (U, Uw)

Geranium family (Geraniaceae)

Storksbill (Erodium erectorum) $(\mathrm{H})$

Oleaster family (Elaeagnaceae)

Buffaloberry (Shepherdia argentea) (H)

Evening primrose family (Onagraceae)

Panicle willowseed (Epilobium paniculatum) (H)

Gaura (Gaura coccinea) (H)

Hemp family (Moraceae)

Hemp (Cannabis sativa) (H)

Milkweed family (Asclepiadaceae)

Milkweed (Asclepias incarnata) (N)

Milkweed (Asclepias tuberosa) (N)

Morning glory family (Convolvulaceae)

Bindweed (Convolvulus repens) (H)

Borage family (Boraginaceae)

Field gromwell (Lithospermum arvense) $(\mathrm{H})$

Nightshade family (Solanaceae)

Buffalo-bur (Solanum rostratum)

Potato (Solanum tuberosum) (U, Uw)

Honeysuckle family (Caprifoliaceae)

Red snowberry (Symphoricarpos rotundifolius vaccinioides) (N)

Sunflower family (Compositae)

Field salsify (Tragopogon pratensis) (H)

Prickly lettuce (Lactuca scariola) (H) 


\section{Common sowthistle (Sonchus oleraceus) (H) \\ Prickly sowthistle (Sonchus asper) (H) \\ Common dandelion (Taraxacum vulgare) $(\mathrm{H})$ \\ Curlycup gumweed (Grindelia squarrosa) (H) \\ Common sunflower (Helianthus annuus) $(\mathrm{H})$ \\ Beggarticks (Bidens frondosa) (H) \\ Bigleaf sumpweed (Iva xanthifolia) (H) \\ Giant ragweed (Ambrosia trifida) (H) \\ Lesser ragweed (Ambrosia artemisiaefolia) (H) \\ Sagebrush (Artemisia sp.) (H) \\ Bull thistle (Cirsium lanceolatum) (H) \\ Roadside thistle (Cirsium discolor) (H) \\ Great burdock (Arctium lappa) (H)}

Table 15. A taxonomic list of the animal food items found in the crops of 500 ring-necked pheasants analyzed during this study .

Phylum Annelida

Class Chaetopoda

Earthworm (Lumbricus sp.) (N)

Phylum Mollusca

Class Gastropoda

Fresh water snail (Heliosoma sp.) (N)

Fresh water snail (Physella heterostropha) (N)

Fresh water snail (Fossaria sp.) (N)

Slug (Derocerus sp.) (H)

Class Pelecypoda

Freshwater clam

Phylum Arthropoda

Class Myriopoda

Centipede (Lithobius forficatus) (N)

Centipede (Scolopocryptops sp.) (N)

Centipede sp. (N)

Milipede (Spirobilus sp.) (N)

Centipede Geophilus sp.) (N)

Class Insecta

Milipede sp. (N)

Order Orthoptera (Grasshoppers, etc.)

Family Acrididae (Short-horned grasshoppers)

Melanoplus mexicanus $(\mathrm{H})$

Melanoplus femur-rubrum (H)

Family Tettigonildae (Long-horned grasshoppers)

Slender meadow grasshopper (Conocephalus fasciatus) (N)

Mormon cricket, Anabrus simplex) (H)

Family Gryllidae (Crickets)

Tree cricket (Oecanthus sp.) (U)

Small field cricket (Nemobius sp.) (H)

Field cricket (Gryllus assimilis) (H)

Order Trichoptera (Case flies)

Caddis fly (sp.) (N)

Order Homoptera

Family Fulgoridae (Lantern flies)

Lantern fly (Scolops sp.) (N)

Family Cercopidae (Spittlebugs)

Spittle bug (Cercopid sp.) (N) 
Family Membracidae (Treehoppers)

Buffalo treehopper (Ceresa bubalus) (H)

Treehopper (Cyrtolobus sp.) (H)

Family Cicadellidae (Leafhoppers)

Lateral leafhopper (Oncemetopius lateralis) $(\mathrm{H})$

Aceratagallia sanguinolenta $(\mathrm{H})$

Dorcephalus platyrhynchus $(\mathrm{H})$

Order Hemiptera (Bugs)

Family Miridae (Leaf bugs)

Tarnished plant bug (Lygus elisus) (H)

Chinch bug (Lygus sp.) (N?)

Superb plant bug (Adelphocoris superbus) $(\mathrm{H})$

Labops hirtus $(\mathrm{H})$

Leaf bug (Mirid sp.) (H)

Family Anthocoridae (Minute pirate bugs)

Minute pirate bug (Anthocorid sp.) (U)

Family Nabidae (Damsel bugs)

Damsel bug (Nabis alternatus) (U)

Damsel bug (Nabis sp.) (U)

Family Reduviidae (Assassin bugs)

Rapacious soldier bug (Sinea diadema) (U)

Family Lygaeidae (Chinch bugs)

Chinch bug (Lygaeus sp.) (N)

False chinch bug (Nysius ericae) (H)

False chinch bug (Nysius sp.) (H)

Big-eyed bug (Georcoris sp.) (H)

Family Pentatomidae (Stink bugs)

Coenus delius $(\mathrm{H})$

Family Cynidae (Negro bugs)

Negro bug (Galgupha atra) (U)

Family Scutelleridae (Shield bugs)

Alternate shield bug (Eurygaster alternatus) (N?)

Order Coleoptera (Beetles)

Family Carabidae (Predaceous ground beetles)

Seed corn beetle (Agnoderus comma) (H)

Platynus sp. (N)

Pterostichus sp. (N)

Amara sp. (N)

Ground beetle (Harpalus sp.) (H)

Lebia sp. (U)

Carabid sp. larva $(\mathrm{H})$

Family Staphylinidae (Rove beetles)

Bledius armatus (H?)

Philonthus varians (H?)

Staphylinid sp. (N)

Family Histeridae (Hister beetles)

Hister beetle (Hister sp.) (N)

Family Cantharidae (Leather-winged beetles)

Silis abdominalis (U)

Family Silphidae (Carrion Beetles)

Spinach carrion beetle (Silpha bituberosa) (H)

Family Shaeriidae

Sphaeridium scarabaeoides) (N)

Family Byrrhidae (Pill beetles)

Pill beetle (Morychus oblongus) $(\mathrm{H})$

Pill beetle (Byrrhid sp.) (H) 
Family Elateridae (Wireworms)

Click beetle (Aeolis dorsalis) (H)

Wireworm (Elaterid sp.) (H)

Family Erotylidae (Pleasing fungus beetles)

Pleasing fungus beetle (Erotyllid sp.) (H)

Family Tenebrionidae (Darkling ground beetles)

Small darkling ground beetle (Blapstinus sp.) (H)

Family Anthicidae (Ant-like flower beetles)

Ant-like flower beetle (Anthicid sp.) (H)

Family Meloidae (Blister beetles)

Blister beetle (Epicauta sp.) (H)

Family Mordellidae (Tumbling flower beetles)

Tumbling flower beetle (Mordellid sp.) (H)

Family Scarabaeidae (June beetles)

Aphodius inquinatus (N)

Aphodius fimetarius (N)

Āphodius sp. (N)

Onthophagus hecate $(\mathrm{H})$

Scarabaeid sp. larva (?)

Family Chrysomelidae (Leaf beetles)

Green dock beetle (Gastroidea dissimilis) (N)

Black-legged tortoise beetle (Jonothonota nigripes) (N)

Myochrus squamosus (H)

Oedionychis vians $(\mathrm{H})$

Banded flea beetle (Systena tianata) $(\mathrm{H})$

Calligrapha lunata (N)

Monoxia sp. (H)

Pachybrachys sp. (N)

Chrysomelid sp. (H)

Family Curculionidae (Weevils)

Dyslobus alternans $(\mathrm{H})$

Strawberry root weevil (Brachyrhinus ovatus) $(\mathrm{H})$

Tanymecus confusus $(\mathrm{H})$

Billbug (Sphenophorus sp.) (H)

Clover root curculio (Sitona sp.) (H)

Pantomorus candidus $(\mathrm{H})$

Lixus sp. ( $\mathrm{H})$

Hyperodes sp. (H)

Gerstaeckeria sp. (H)

Radish weevil (Cleonis sp.) (H)

Calandra sp. $(\mathrm{H})$

Curculionid sp. (H)

Curculionid sp. larva $(\mathrm{H})$

Coleoptrus grub (unidentified) (H?)

Order Lepidoptera

Family Coleophoridae (Case bearers)

Leaf miner (Coleophorid sp. larva) (H?)

Family Pyralidae (Snout moths)

Sugar beet webworm (Loxostege sticticalis) (H)

Pyralid sp. larva (H?)

Family Crambidae

Crambus sp. (H)

Family Geometridae (Measuring worms)

Green geometrid catepillar (Geometrid sp.) (H) 
Family Noctuidae (Cutworms)

Dinghy cutworm (Feltia ducens) (H)

Bronzed cutworm (Nephelodes emmendonia) (H)

Cutworm sp. $(\mathrm{H})$

Family Arctiidae (Tiger moths)

Arctiid sp. caterpillar (H)

Family Pieridae (Sulphur and white butterflies)

Alfalfa butterfly caterpillar (Eurymus eurytheme) $(\mathrm{H})$

Cabbage worm (Pierid sp. larval) (H)

Order Diptera (Flies)

Orthorraphous maggot (N)

Family Bibionidae (March flies)

Bibio sp. (H?)

Family Bombyliidae (Bee flies)

Bombyliid sp. larva (U)

Cyclorrhapid maggot (H?)

Family Ortalidae (Ortalids)

The ortalid (Anacampta latiuscula) (H)

Family Sarcophagidae (Flesh flies)

Sarcophagid sp. (H)

Order Hymenoptera (Bees, wasps, ants)

Family Tenthridinidae (Sawflies)

Tenthridinid sp. larva $(\mathrm{H})$

Family Ichneumonidae (Ichneumon wasps) Ichneumonid wasps sp. (U)

Family Formicidae (Ants) Ant sp. (H)

Family Andrenidae (Burrowing bees) Andrenid sp. (U)

Family Apidae (Bees) Honeybee (Apis mellifica) (U)

Class Arachnida (Spiders)

Harvestmen (Pholcus phalangioides) (U)

Orb-weaver (Argiope aurantia) (U)

Philodromus pernix (U)

Clubionid sp. (U)

Pirata maxi (U)

Wolf spiders (Lycosid sp.) (U)

Unidentified spider sp. (U)

Phylum Chordata (Chordates)

Class Pisces (Fish)

Carp fragments (Cyprinus sp.) (N)

Class Aves (Birds)

Eggshell fragments (Phasianus colchicus torquatus) 
